\title{
BILINGUAL EDUCATION AND DESEGREGATION
}

Preventing the isolation of minority students in public schools has been a central aim in civil rights litigation. In the landmark decision Brown v. Board of Education, ${ }^{1}$ the Supreme Court attacked one facet of that isolation, racial segregation. The Court ruled that deliberate separation of minority students violates the equal protection clause: ${ }^{2}$ "[s]eparate educational facilities are inherently unequal." 3 In a series of decisions following Brown, the Supreme Court delineated the scope of the state's duty and the types of equitable remedies courts should employ to enforce the constitutional mandate. ${ }^{4}$

The issue of minority isolation arose also in the context of an integrated classroom. In Lau v. Nichols, 5 non-English speaking Chinese students alleged that teaching classes only in English deprived them of a meaningful education. The Supreme Court agreed, ruling that Title VI of the Civil Rights Act of $1964^{6}$ required compensatory programs. Following Lau, bilingual-bicultural programs were developed to ease the difficulties of linguistically disadvantaged students. ${ }^{7}$

Problems soon arose in attempting to design compensatory programs which would not violate the duty imposed by the desegregation decisions. Did Lau imply that a remedial program providing separate but more than equal education to minorities was constitutionally acceptable, or did it require that remedial education be integrated? Is the choice to be left to the school board?

This Comment will examine the rights of school children and the discretion afforded school districts in complying with the dual

1347 U.S. 483 (1954).

2 The fourteenth amendment provides in pertinent part:

No State shall make or enforce any law which shall abridge the privileges or immunities of citizens of the United States; nor shall any State deprive any person of life, liberty, or property, without due process of law; nor deny to any person within its jurisdiction the equal protection of the laws.

U.S. ConsT. amend. XIV.

3 Brown v. Board of Educ., 347 U.S. 483, 495 (1954).

4 See, e.g., Dayton Bd. of Educ. v. Brinkman, 433 U.S. 406 (1977); Keyes v. School Dist. No. 1, 413 U.S. 189 (1973); Swann v. Charlotte-Mecklenburg Bd. of Educ., 402 U.S. 1 (1971).

5414 U.S. 563 (1974).

B "No person in the United States shall, on the ground of race, color, or national origin, be excluded from participation in, be denied the benefits of, or be subjected to discrimination under any program or activity receiving Federal financial assistance." Section 601,42 U.S.C. $\$ 2000 \mathrm{~d}$ (1976).

7 See, e.g., Colo. REv. STAT. $\$ 22-24$ (Supp. 1978); note 75 infra. 
mandates of Brown and Lau. The first two sections argue that bilingual education and integration are theoretically and empirically compatible. Section III explores the state's duty to integrate schools, as that duty is defined by the Constitution and pertinent statutes. Constitutional and statutory mandates are also the focus of the next two sections which examine the duties to provide bilingual education and to integrate bilingual classrooms. Finally, section VI evaluates the usefulness of bilingual programs as part of desegregation remedies.

\section{The Theoretical Compatibility of Integration and Bilingual-Bigulturat Education}

Given the constitutionally based policy in favor of integrating students of all races, ${ }^{8}$ demands for bilingual education are troublesome. If integration means the nonrecognition of differences among students, bilingual programs necessarily conflict because they explicitly recognize that students are not the same. On the other hand, if integration is viewed as an opportunity to share the cultural richness and diversity each student brings to the classroom, integrated bilingual-bicultural classrooms will facilitate that sharing. The equal protection clause, developed by a society concerned about the physical separation of blacks and whites, ${ }^{9}$ is silent on which interpretation of integration is most appropriate, and the case law provides no clearer clue.10 One's view on the theoretical compatibility of integration and bilingual education is dictated largely by one's policy choices in defining the goals of integration. ${ }^{11}$

\section{A. The Conflict View}

According to one theory, integration and bilingual education are conflicting goals. Integration is intended to promote the fusion

8 See notes 56-64 infra \& accompanying text.

9 The fourteenth amendment, passed in the aftermath of the Civil War, was meant originally to prevent discrimination against blacks. Slaughter-House Cases, 83 U.S. (16 Wall.) 36 (1873). See R. Fernández \& J. Guskin, Bilingual Education and Desegregation: A New Dimension in Legal and Educational Decision-Making 7-8 (1977) (unpublished paper, University of Wisconsin, Milwaukee).

10 The case law, in fact, suggests that "integration is as consistent with cultural pluralism as it is with assimilation." Comment, Cultural Pluralism, 13 HARv. C.R.C.L. L. REv. 133, 143 (1978). The Court in Brown v. Board of Educ., 347 U.S. 483 (1954), "did not indicate that an integrated society would preclude the preservation of a distinct cultural heritage for blacks." Cultural Pluralism, supra at 143.

11 For a discussion of the differences between assimilationist and pluralist goals, see Foster, Bilingual Education: An Educational and Legal Survey, 5 J.L. \& EDvc. 149 (1976). The author notes that "[a]ssimilation is a function which generally seems to follow from the dominant culture's need to ameliorate social problems," whereas pluralism, "while attentive to social problems, stresses more the basic values of a society committed to diversity." Id. 155 . 
of groups, to allow students to view the similarities among their classmates. By eliminating the differences among people, a distinctly "American" culture will emerge. The adherents of this position, cultural monists, see bilingual-bicultural education as anathema. ${ }^{12}$ Recognition of the separate languages and cultures of minority groups hinders assimilation.

Some cultural monists might acquiesce in what Rolf Kjolseth has labeled an assimilationist model of bilingual education, which sees bilingual education as a step to acquisition of the Anglo culture. Non-English speaking students will be taught English and then transferred to the monolingual program as soon as proficiency is achieved.13 Even this limited use of bilingual education can be accepted by monists only as a necessary, temporary evil.

This assimilationist focus was recently adopted by the Ninth Circuit in Guadalupe Organization, Inc. v. Tempe Elementary School District No. 3.14 Non-English-speaking Mexican-American and Yaqui Indian students sued to compel implementation of a bilingual education program in place of a program of remedial learning. In rejecting the plaintiffs' claim that bilingual education is required by the equal protection clause, the court stated:

Linguistic and cultural diversity within the nationstate, whatever may be its advantages from time to time, can restrict the scope of the fundamental compact. Diversity limits unity. Effective action by the nation-state rises to its peak of strength only when it is in response to aspirations unreservedly shared by each constituent cul-

12 The cultural monist approach to integration is not, however, inherently incompatible with bilingual-bicultural education. If society is viewed as a melting pot comprising a blend of various cultures rather than an embodiment of the majority's values, the cultural monist sees bilingual education as a means of furthering the unity of the evolving structure. The ideal, according to this view of the melting pot, would be integration of every school according to the respective percentages of the various subcultures in the general population. Cf. DeFunis v. Odegaard, 416 U.S. 312, 334 (1974) (Douglas, J., dissenting) ("The melting pot is not designed to homogenize people, making them uniform in consistency. The melting pot as I understand it is a figure of speech that depicts the wide diversities tolerated by the First Amendment under one flag."). See also Cultural Pluralism, supra note 10, at 135.

13 Kjolseth, Bilingual Education Programs in the United States: For Assimilation or Pluralism? in BIIINGUALISM IN THE SOUTHWEST 3, 11 (1973). An assimilationist model of bilingual education encourages rapid and near complete transfer to a nonethnic standard, gives school administrators total program control, employs teachers as role models of Anglo culture, and ignores local dialects. Id. 12-14. Kjolseth estimates that at least eighty percent of bilingual programs approximate this model. Id. 15-16.

14587 F.2d 1022 (9th Cir. 1978). The court held that, "[a]ssuming adequate remedial instruction, education in English, reflecting American culture and values only, is not a discriminatory course of conduct." Id. 1029. 
ture and language group. As affection which a culture or group bears toward a particular aspiration abates, and as the scope of sharing diminishes, the strength of the nationstate's government wanes. ${ }^{15}$

Additionally, the court bolstered its assimilationist stance by reading narrowly the Givil Rights Act of $1964^{16}$ and the Equal Education Opportunity Act of $1974^{17}$ as not requiring implementation of bilingual-bicultural programs. ${ }^{18}$

\section{B. The Compatibility View}

An alternative position, the pluralist approach, sees bilingual education and desegregation as mutually supportive. ${ }^{19}$ Integration is meant to instill mutual appreciation among groups and to crumble stereotypes by fostering understanding of the cultural differences among people. Contact with different types of persons results in enriched lives and broadened outlooks. The very differences may even be a source of cohesion as each group is both "teacher" and "student." At the very least, mutual appreciation will promote acceptance and respect. ${ }^{20}$

A pluralist model of bilingual education ${ }^{21}$ reinforces the goals of integration. Bilingual education is aimed at increasing the selfrespect of minority students by teaching their own culture and lan-

15 Id. 1027.

Taking an opposing point of view, the New Mexico State Department of Education has found that an assimilationist program "tends to deny the realities of the world which the child will experience outside the academic environment, as well as place strictures on his ability to learn within the school." Statement of Bilingual Teacher Training Unit, New Mexico State Department of Education 3 (Eric No. ED 129-084, 1976).

16 Title VI, $\$ 601,42$ U.S.C. $\$ 2000$ d (1976). For further discussion of this issue, see notes 76-110 infra \& accompanying text.

17 Section 204,20 U.S.C. $\$ \$ 1703,1703$ (f) (1978). For further discussion of this issue, see notes $111-21$ infra \& accompanying text.

18 Guadalupe Org., Inc. v. Tempe Elem. School Dist. No. 3, 587 F.2d 1022, 1029-30 (9th Cir. 1978).

19 Cultural pluralism does not necessarily imply compatibility of bilingual education and integration. If the melting pot is seen as a blend of various subcultures, see note 12 supra, the pluralist may encourage segregation because integration would lead to a monist society. therein.

20 See Cultural Pluralism, supra note 10, at 136, and the authorities cited

21 Kjolseth defined a pluralist model of bilingual education as one which encourages use of both languages in and out of the school, reinforces and develops the native culture, uses native dialects, employs teachers as bicultural role models, and seeks to obtain parental support through adult bilingual education programs. Kjolseth, supra note 13, at 1-11. 
guage. ${ }^{22}$ Students proud of their cultural heritage provide a more confident and knowledgeable resource for other students. Anglos in a bilingual-bicultural classroom have the advantage of exposure to a culture they might not otherwise experience. Although nonAnglos may have other means outside the school for acquiring an appreciation of Anglo culture, an integrated classroom conceivably provides one of the few opportunities for associating with Anglos as peers in an environment fostering respect for both cultures. Recognition of all cultures benefits all students, and mutual appreciation increases. ${ }^{23}$

Some support for the values embodied in the pluralist model of integration are found in Justice Powell's opinion in Regents of the University of California v. Bakke. ${ }^{24}$ In Bakke, a white medicalschool applicant successfully challenged the school's practice of reserving a certain number of spaces for minority applicants. Justice Powell found compelling the state interest in fostering diversity in the composition of the student body:

Physicians serve a heterogeneous population. An otherwise qualified medical student with a particular background -whether it be ethnic, geographic, culturally advantaged or disadvantaged-may bring to a professional school of medicine experiences, outlooks and ideas that enrich the training of its student body and better equip its graduates to render with understanding their vital service to humanity. ${ }^{25}$

22 Bilingual education is the use of two languages one of which is English, as mediums of instruction for the same pupil population in a well organized program which encompasses part or all of the curriculum and includes the study of the history and culture associated with the mother tongue. A complete program develops and maintains the children's self-esteem and a legitimate pride in both cultures.

U.S. Office of Educ., Programs Under Bminguat Education Agt (Title VII, ESEA), Manual for Project Applicants and Grantees 1 (1970).

23 [A]ctual integration of students and faculty at a school, by setting the stage for meaningful and continuous exchanges between the races, educates white and Negro students equally in the fundamentals of racial tolerance and understanding. ... [L] [earning to live interracially is, or in a democracy should be, a vital component in every student's educational experience.

Elementary school integration enables the very young of either race to accept each other as persons before racial attitudes and prejudices have a chance to intrude and harden; Negro and white children playing innocently together in the schoolyard are the primary liberating promise in a society imprisoned by racial consciousness.

Hobson v. Hansen, 269 F. Supp. 401, 419 (D.D.C. 1967), aff'd and remanded sub nom. Smuck v. Hobson, 408 F.2d 175 (D.C. Cir. 1969) (citations omitted). This concept of mutual appreciation would seemingly include also the cultural and linguistic traits of minority groups.

24438 U.S. 265 (1978).

25 Id. 314 (footnote omitted) (Powell, J.). 
Justices Brennan, White, Marshall, and Blackmun also found the school's admission program "sufficiently important to justify use of race-conscious admissions criteria." 26 Just as diversity can enrich a medical school program, so it can enrich an elementary school program. Integration and pluralism in an elementary school may thus further the same values recognized by five Justices in Bakke.

Although Justice Powell and the Ninth Gircuit ${ }^{27}$ differed regarding the values of assimilation and pluralism, neither suggested that the Constitution favors one of these approaches. ${ }^{28}$ Bilingual education may therefore be regarded as theoretically compatible with the goals of integration.

\section{The EMpiricat Compatibility of Integration and Bilingual EdUCATION}

Regardless whether homogeneity or diversity is socially desirable, an educational program's effectiveness in teaching students basic linguistic skills and substantive knowledge is of crucial importance. If bilingual techniques are not beneficial for English speaking students, integrating bilingual education classes may be pedagogically unsound. If, on the other hand, both English and non-English speaking students learn as well in bilingual as in monolingual classrooms, integration will not sacrifice educational quality. Central to the subsequent legal analysis exploring whether integrated bilingual classes are constitutionally required is an assessment of the educational effects of bilingual education. ${ }^{29}$

The major nationwide study assessing the impact of bilingual education programs in the United States was performed by the part).

${ }^{26} I d .362$ (Brennan, J, concurring in the judgment in part and dissenting in

27 See notes 14-18 supra \& accompanying text.

28 The Ninth Circuit adopted a neutral stance: "[T]he Constitution neither requires nor prohibits the bilingual and bicultural education sought by the appellants. Such matters are for the people to decide." Guadalupe Org., Inc. v. Tempe Elem. School Dist. No. 3, 587 F.2d 1022, 1027 (9th Cir. 1978). Similarly, Justice Powell did not assert in Regents of the Univ. of Cal. v. Bakke that the Constitution requires states to aim for diversity in the student body. 438 U.S. 265, 314 (1978) (Powell, J.). The absence of a constitutional policy with regard to assimilation and pluralism stands in contrast to the well established Constitutional presumption supporting integration, see notes 56-64 infra \& accompanying text.

29 If an Anglo child's education in a bilingual classroom is inferior to that he would receive in a monolingual classroom, such a harm might tip the constitutional balance against requiring integration of bilingual classrooms. Specifically, avoiding such a harm might qualify as a compelling state interest and justify racially separate bilingual classrooms. See note 203 infra \& accompanying text. 
American Institute for Research in the Behavioral Sciences (AIR). ${ }^{30}$ Conducted from 1975 to 1977 , the AIR study evaluated the achievement of over 11,500 students in 384 classrooms. The research spanned 150 schools and thirty-eight different sites. ${ }^{31}$ Tests measured student performance in English oral comprehension and reading, Spanish oral comprehension and reading, and mathematics. ${ }^{32}$ Students in bilingual projects funded by the federal government under the Bilingual Education Act, Title VII of the Elementary and Secondary Education Act, ${ }^{33}$ were tested both at the beginning and end of the 1975-76 school year. ${ }^{34}$ The results were compared with the results of similar tests administered to students not in Title VII bilingual programs. A third test was given to a subsample of second and third grade students the following fall to evaluate their retention of subject matter over the summer. ${ }^{35}$

In addition to comparing Title VII and non-Title VII students, the study was designed to uncover those characteristics of students or teachers most associated with high achievement in bilingual classrooms. In analyzing the test results, researchers classified students according to ethnicity, socioeconomic status, age, and sex. ${ }^{36}$ Teachers and aids were categorized according to their qualifications, measured by training, experience, and bilinguality. ${ }^{\mathbf{3 7}}$ Study directors then compiled survey results for each of the categories to determine the degree of correlation with student achievement. ${ }^{38}$

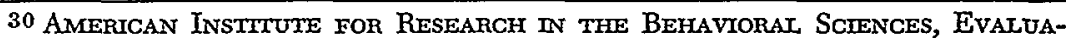

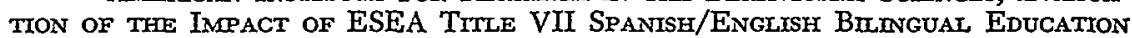
Program [hereinafter cited as AIR Study]. The study's results are published in three volumes: Volume I (ERIC No. ED 138-090, 1977); Volume II (ERIC No. ED 138-091, 1977); Volume III (ERIC No. ED 154-635, 1978). A fourth volume (ERIC No. ED 154-634, 1978) provides an overview of the study and findings [hereinafter cited as Overview].

31 Id. Overview, supra note 30 , at 3.

32 Id. 6. Student attitudes were also tested.

33 Sections 701-751, 20 U.S.C. $\$ \$ 3221-3261$ (Supp. 1979). All projects examined were at least in their fifth year of funding under Title VII.

34 Overview, supra note 30 , at 2.

$35 \mathrm{Id}$.

36 Id. 3.

$37 \mathrm{Id}$.

38 Some commentators feel that the study's methodological defects give the results little credence. See, e.g., Intercultural Development Research Ass'N, The AIR Evaluation of the Impact of ESEA Titue VII Spanish/English BIlingual Education Programs (ERIC No. ED 151-435, 1977) (with summary by Dr. Jose Cardenas) [hereinafter cited as IDRA Response]; T. GRAY, Response to AIR Study "Evaluation of tho IMPact of ESEA Title VII Spantsh/ENglish Bingudal Education Program" (ERIC No. ED 138-122, 1977). Although these objections seem somewhat overstated, the study may be validly criticized in three areas: inadequacy and lack of uniformity of the bilingual programs sampled; in- 


\section{A. Class Composition}

Descriptions of the composition of Title VII ${ }^{39}$ classes were the most striking findings of the AIR study:

Generally, less than a third of the students in the Title VII classrooms were there because of their need for English instruction (limited proficiency in English) as judged by the classroom teacher. For students of Hispanic background, $35 \%$ in the second-grade Title VII classrooms were there because of their need for English instruction. For grades 3, 4, 5, and 6, the corresponding percentages were, respectively, $30 \%, 29 \%, 19 \%$, and $27 \% .{ }^{40}$

Title VII programs are not, therefore, primarily a vehicle to teach non-English speaking students substantive subject matter while they

adequacy and lack of uniformity of the comparison groups; and improper use of testing and statistical methods.

The bilingual programs sampled varied widely in teacher qualifications and teaching techniques. IDRA Response, supra at 10. Although AIR purportedly examined the effect of teacher qualifications on student performance, AIR STODY, stipra note 30 , at VIII- 1 to 2 , the crudeness of the qualifications assessment undercuts the validity of the finding. IDRA Response, supra at iii, 13-14. Almost half the bilingual teachers may not have attained fluency in Spanish, id. iv, 17, and may therefore have conducted some of the bilingual programs entirely in English. The wide variety of program goals and teaching techniques also makes the Title VII category subject to considerable intragroup variation, perhaps affecting the validity of the statistical techniques.

The AIR Study also did not accurately establish comparison groups. An estimated one-third of the teachers and aids labeled non-Title VII were involved in a bilingual program. Id. iii. If these teachers utilized their foreign language skills or bilingual-bicultural teaching techniques on students in the control group, comparing Title VII and non-Title VII programs may not reveal much about bilingual education. Moreover, the validity of the comparison is diminished by the occasional failure to choose non-Title VII students with the same curriculum or in the same school district as the Title VII group. Id. ii-iii, 4. IDRA alleges that this shortcoming has a substantial impact on the AIR results, in fact that $50 \%$ of the Title VII group did not have a non-Title VII comparison. Id. 5-6.

Testing and statistical techniques may have further distorted the results. In approximately fifty percent of the classrooms, pretests and posttests were conducted within a five-month span, allowing little time for classroom techniques to become effective. Id. iii, 9. But see 3 AIR SToDy, supra note 30, at II-47 (differences in time spans were examined to determine possible effect on results). The English language achievement tests had not been proven reliable for limited English speaking students. Grax, supra at 2. Finally, teacher assessment of student language ability may be inaccurate. IDRA RESPONSE, supra at ii, 2.

Because of these defects in the AIR methodology, the results are not mathematically precise, but only rough measures of the success of bilingual programs. The study results nevertheless provide some valuable insights, especially where simple, class composition data, not subject to most of these methodological flaws, were compiled, rather than statistical analyses performed.

39 Sections 701-751, 20 U.S.C. §§ 3221-3261 (Supp. 1979).

40 Overview, supra note 30 , at 10 . 
acquire English. On the contrary, the programs in operation teach far more students who speak English than who require remedial instruction. These findings are certainly surprising, especially in light of the avowed Title VII purpose to teach students of limited English speaking ability ${ }^{41}$ and the explicit denial of an intent to teach a language other than English. ${ }^{42}$

The class composition data take on added significance when the English speaking group is scrutinized. AIR researchers discovered that seventy-five percent of the students in bilingual classrooms were Hispanic; ${ }^{43}$ in fact, English speaking Hispanics constituted a plurality in the Title VII classrooms. Because participation in these programs is optional for English speaking students, ${ }^{44}$ these data obviously indicate that some Hispanic students fluent in English prefer bilingual classes. Similarly, few of the Hispanic students with limited English speaking ability chose to leave when able to function in English.45 Apparently, bilingual education serves to satisfy various linguistic and cultural needs of minorities. Rather than isolating only those students in need of remedial instruction, optional bilingual programs are separating also those minorities able to speak English. ${ }^{46}$

\section{B. Achievement}

The AIR data confirm neither the hypothesis that students of limited English speaking ability are substantially benefited by bilingual programs nor the theory that Anglo students are substantially harmed. For Hispanic students with limited English speaking ability, AIR discovered that achievement relative to national norms in English and vocabulary remained constant between pretest and posttest. ${ }^{47}$ Because almost all students of limited English speaking ability were in the Title VII ${ }^{48}$ programs, whether they were better off in bilingual classes than they would have been without these

41 Section 703, 20 U.S.C. $\$ 3223(\mathrm{a})(4)($ A) (Supp. 1979).

42 Id. See Overview, supra note 30 , at 10-11.

43 Overview, supra note 30 , at 8.

44 Section 703, 20 U.S.C. $\$ 3223$ (a) (4)(B) (Supp. 1979).

45 Overview, supra note 30 , at 10 . This does not necessarily mean that the programs follow the "maintenance model," that they seek to maintain the Spanish language and encourage its use outside of the classroom. See Kjolseth, supra note 13 , at 9 .

46 For a discussion of the causes of these data, see notes 191-94 infra \& accompanying text.

471 AIR STUDr, supra note 30, at VI-76.

48 Sections 701-751, 20 U.S.C. $\$ \S 3221-3261$ (Supp. 1979). 
programs is unclear. ${ }^{49}$ Certainly, the gap between themselves and their Anglo peers is not closing rapidly.

The English language gain of English speaking Title VII students was not as great as the gain of comparable non-Title VII students. In fact, the achievement of Anglo students declined appreciably relative to national norms. ${ }^{50}$ Anglo Title VII students were learning, but not as fast as their non-Title VII counterparts.

The mathematics and Spanish test results differed. In mathematics, all groups in bilingual classes showed gains relative to the national norms. ${ }^{51}$ Moreover, Spanish reading test scores for all Title VII students increased. ${ }^{52}$ Indeed, the opportunity for Spanish language acquisition and development was an advantage unique to the Title VII classrooms, and the slower English language growth rate for English speaking Title VII students is conceivably attributable to the attention given to Spanish in addition to English in those classrooms. ${ }^{53}$

The achievement test results do not demonstrate a substantial overall harm to Anglos participating in bilingual programs. Nevertheless, some tradeoffs are involved. English speaking students in bilingual programs acquire mathematics skills at the same rate as their non-Title VII counterparts, but are learning English language arts at a slower rate. In exchange, they are acquiring a second language and exposure to a second culture.

The AIR study results are inconclusive, and more research is necessary. ${ }^{54}$ The final determination of the educational soundness

49 If bilingual programs are not helping limited English speaking students, they are failing to remedy the lack of meaningful education found in Lau v. Nichols, 414 U.S. 563 (1974). Bilingual education is based on the premise, generally accepted among educators, that students learn better in their native language than in a foreign language. See Gaardner, Statement to the Special Subcommittee on Bilingual Educ. of the Comm. on Labor and Public Welfare, U.S. SENate, 90th Cong., 51-55 (1967) reprinted in The Language Edvcation of Minontry ChIIDREN 51-52 (1972). In one review of the existing empirical research, bilingual education was found generally to have had positive effects for linguistic minorities. L. ZAPPERT \& B. Cruz, Bilngual Eddcation: An Appratsal of Emprrical Research (ERIC No. ED 153-758, 1977).

501 AIR STUDx, supra note 30 , at VI-77.

61 Id. 90.

52 Id. VII-5. The progress of Title VII students in Spanish reading could not be compared with that of non-Title VII students because the latter were not taught Spanish.

53 The study also found "no clear trend" indicating that Title VII participation had a positive impact on students' attitudes toward school. Id. VIII-5.

54 The study does not measure the effects of forced bilingual integration. The few Anglos in the program attended voluntarily. An Anglo child forced into a bilingual class may not be as receptive to the bilingual curriculum, and the results may thus be less positive. See note 203 infra. 
of integrated bilingual programs may depend on a policy choice between the tradeoffs and competing values.

\section{The Developing Legal Doctrine: The Duty to InTEgrate}

Defining the right of minority school children to obtain a meaningful education in an integrated environment and the concommitant duty of school districts to uphold this right has been an emotional and often complex process. The statutory and constitutional fabric of desegregation has become much more extensive and sophisticated since the duty to provide integrated schools was first established in 1954 in Brown v. Board of Education. ${ }^{55}$ The Supreme Court has not yet satisfactorily delineated the twin components of this right as they operate separately, much less in tandem. Before evaluating the constitutionality of segregated bilingual classrooms, one must first define unlawful educational segregation of ethnic minorities and the school district's duty to provide education in a language the student can understand.

\section{A. The Constitutional Mandate}

In Brown v. Board of Education, the Supreme Court held that the equal protection clause prohibits states from deliberately segregating students by race.56 In subsequent decisions the Court has categorized racial classifications as "suspect" and has ruled that any statute or practice separating individuals on that basis can be upheld only if able to withstand analysis under the strictest level of judicial scrutiny. ${ }^{57}$ A state may thus intentionally separate students by race only after showing "that its purpose or interest is both constitutionally permissible and substantial, and that its use of the classification is 'necessary ... to the accomplishment' of its purpose or the safeguarding of its interest." 58 In applying this compelling state interest test, the Court has rarely found segregative state action directed at racial or ethnic minorities constitutionally permissible. ${ }^{59}$

55347 U.S. 483 (1954).

56 Id. 495.

57 See, e.g., Loving v. Virginia, 388 U.S. 1, 11 (1967); McLaughlin v. Florida, 379 U.S. 184, 192 (1964).

58 See, e.g., Regents of the Univ. of Cal. v. Bakke, 438 U.S. 265, 305 (1978) (Powell, J.) (citing In re Griffiths, 413 U.S. 717, 722-23 (1973)). See San Antonio Indep. School Dist. v. Rodriguez, 411 U.S. 1, 16-17 (1973).

59 The difficulty of meeting the compelling state interest test suggests a presumption in favor of integration. Korematsu v. United States, 323 U.S. 214 (1944), and Hirabayashi v. United States, 320 U.S. 81, 100 (1943), however, permitted classifications on the basis of national origin to promote national security during wartime. 
Neutral classifications that have disproportionate racial impacts, as distinguished from the state law invalidated in Brown, do not manifestly evince a purpose on the part of the state to separate individuals on the basis of race. Students challenging the constitutionality of segregation resulting from facially neutral classifications must first demonstrate the state's segregative intent before strict judicial scrutiny is triggered: de facto segregation is not alone sufficient. ${ }^{60}$

If intentional racial segregation is found, the school district must show both a state interest sufficiently compelling to justify that segregation and the unavailability of a less restrictive alternative. A school district unable to meet these burdens, held the Court in Brown, ${ }^{61}$ will be ordered to eliminate all vestiges of the equal protection violation "with all deliberate speed." Brown left unanswered, however, many questions regarding the appropriate remedies. For example, the Court failed to articulate exactly what constitutes a "vestige" and the extent to which a district court is empowered to redistribute students to achieve maximum integration. These questions were resolved partially in Dayton Board of Education v. Brinkman, 62 mandating a "but for test" in determining the appropriate scope of a remedial order. ${ }^{63} \mathrm{~A}$ district court may only place the school system in the position in which it would have been had the violation not occurred.

The Dayton "but for" approach raises two problems. First, the position the school district would have been in might not be the most conducive to learning. Surely a court of equity should be justified in ordering transition to a system more educationally beneficial to all students. Only if additional upheaval would result from the transition should a court be restricted.64 Second, ascertaining how

60 Dayton Bd. of Educ. v. Brinkman, 433 U.S. 406, 419-20 (1977); Washington v. Davis, 426 U.S. 229, 240 (1976). The problem with the intent requirement is that the existence of the detrimental impact of segregation on school children, Brown v. Board of Educ., 347 U.S. 483, 493-95 (1954), does not depend upon whether the segregation is de facto or de jure.

61 Brown v. Board of Educ. (Brown II), 349 U.S. 294, 301 (1955).

62433 U.S. 406 (1977).

63 Id. 420.

64 Courts of equity should balance the costs and benefits of the readjustment caused by each of the plans proposed. The Court's decision in Dayton Bd. of Educ. v. Brinkman, 433 U.S. 406 (1977), protected the whites from paying a greater price for desegregation than the unconstitutional actions of the school board warranted. This approach seems fictional, however, because the white school children were not the perpetrators of the prior violation. Perhaps one reason to permit a court to order complete integration, accompanied by judicial supervision, is the unavoidable suspiciousness of a majority-controlled school board guilty of a prior violation. See notes 191-94 infra \& accompanying text. 
the school district would be operating absent the constitutional violation may be difficult and the court's remedy therefore largely conjectural.

\section{B. The Statutory Requirements}

Although the Supreme Court has issued numerous rulings on public school desegregation under the equal protection clause, it has attempted only infrequently to define the scope of the statutory requirements. Title VI provides: "No person in the United States shall, on the ground of race, color or national origin, be excluded from participation in, be denied the benefits of, or be subjected to discrimination under any program or activity receiving Federal financial assistance." 65

An implementing regulation, Regulation A, was promulgated in 1964 by the Department of Health, Education, and Welfare (HEW). Regulation A prohibits recipients of federal assistance, in selecting types of services and facilities, from using "criteria or administrative methods which have the effect of subjecting individuals to discrimination because of their race, color, or national origin." 68 By forbidding actions with discriminatory effects regardless of the motivation behind them, HEW has seemingly extended the protections of Title VI beyond those afforded by the Constitution. Regents of the University of California $v . B a k k e^{67}$ however, casts doubt on the validity of this regulation. Five Justices agreed there that Title VI goes no further than the Constitution in defining the components of discrimination. ${ }^{68}$

Intentional segregation is also prohibited by the Equal Educational Opportunities Act of 1974: ${ }^{69}$ "No State shall deny equal educational opportunity to an individual on account of his or her race, color, sex, or national origin, by-(a) the deliberate segregation by an educational agency of students on the basis of race, color,

65 Section 601, 42 U.S.C. $\$ 2000 d$ (1976).

6645 C.F.R. $\$ 80.3(\mathrm{~b})(2)$ (1978).

67438 U.S. 265 (1978).

68 Id. 284-87 (Powell, J.), 328 (Brennan, J., concurring in the judgment in part and dissenting in part). Because of HEW's expertise in the field of education, any conflict regarding the scope of Title VI, $\$ 601,42$ U.S.C. $\$ 2000$ d (1976), should arguably be resolved in their favor. $C f$. United Steelworkers v. Weber, 47 U.S.L.W. 4851 , 4854-55 \& n.6 (U.S. June 27, 1979) (Nos. 78-432, 78-435, \& 78-436) (upholding voluntary race-conscious affrmative action under Title VII, $\$ 701,42$ U.S.C. $\$ 2000$ e (1976), and distinguishing Title VI because the former was intended to regulate private decisionmaking and not to incorporate the fifth and fourteenth amendments).

69 Sections 202-223, 20 U.S.C. $\$ \$ 1701-1721$ (1978). 
or national origin among or within schools ...."70 The word "deliberate" indicates that the statute apparently comports with Supreme Court decisions interpreting the fourteenth amendment to include an element of intent. ${ }^{71}$ The statutory prohibitions thus appear to be coextensive with those of the Constitution.

\section{The Duty to Provide Brimgual Edugation}

The requirement that school districts teach students in a language they can understand, though of recent vintage, is becoming forcefully entrenched. The right of non-English speaking students to remedial programs, the sources of which are Title VI of the Civil Rights Act of 1964,72 the Equal Educational Opportunities Act of 1974, ${ }^{73}$ and the equal protection clause, was confirmed in 1974 by the Supreme Court in Lau v. Nichols. ${ }^{74}$ Despite the recent commitment of both the Court and the Congress to remedial language programs, ${ }^{75}$ the scope and foundation of the right to compensatory education remains elusive.

\section{A. The Statutory Requirements}

\section{Title VI}

Although the Supreme Court has not often used Title VI ${ }^{76}$ in the school desegregation area, it has ruled that the statute invalidates school programs having the effect of affording unequal educational opportunity to non-English speaking students. In Lau v. Nichols, ${ }^{77}$ the Supreme Court affirmed the right of 1800 non-

70 Id. $\$ \oint 1703-1703$ (a) (1978) (emphasis supplied). But see id. $\$ 1703(\mathrm{c})$, prohibiting

the assignment by an educational agency of a student to a school, other than the one closest to his or her place of residence within the school district in which he or she resides, if the assignment results in a greater degree of segregation of students on the basis of race, color, sex, or national origin among the schools of such agency than would result if such student were assigned to the school closest to his or her place of residence.

(emphasis supplied).

71 Although most courts have decided school segregation cases on constitutional grounds, at least one has employed id. $\$ 1703(a)$ to invalidate intentional segregation. Cintron v. Brentwood Union Free School Dist., 455 F. Supp. 57, 63 \& n.11 (E.D.N.Y. 1978). This analysis suggests that many cases decided under the equal protection clause should first have been analyzed under Title VI, $\$ 601,42$ U.S.C. $\S 2000 \mathrm{~d}(1976)$.

72 Section 601, 42 U.S.C. $\$ 2000$ d (1976).

73 Section 204, 20 U.S.C. \$1703(f) (1978).

74414 U.S. 563 (1974).

75 See, e.g., Bilingual Education Act, $\$ \$ 701-751,20$ U.S.C. $\$ \$ 3221-3261$

(Supp. 1979) (granting federal funds for bilingual and other special projects).

70 Section 601, 42 U.S.C. $\$ 2000$ d (1976).

77414 U.S. 563 (1974). 
English-speaking Chinese students in the San Francisco School District to a remedial program specially tailored to their needs. The Court found that offering the same services to all students was simply inadequate:

Under these state-imposed standards there is no equality of treatment merely by providing students with the same facilities, textbooks, teachers, and curriculum; for students who do not understand English are effectively foreclosed from any meaningful education.

Basic English skills are at the very core of what these public schools teach. Imposition of a requirement that, before a child can effectively participate in the educational program, he must already have acquired those basic skills is to make a mockery of public education. We know that those who do not understand English are certain to find their classroom experiences wholly incomprehensible and in no way meaningful. ${ }^{78}$

The Court's willingness to extend Title VI to authorize a special program is attributable to the clear mandate of HEW's Regulation $\mathrm{A}^{79}$ and a $1970 \mathrm{HEW}$ memorandum. ${ }^{80}$ The memorandum states that programs having the effect of excluding students because of linguistic differences are violative of Title VI and must be remedied by affirmative programs. ${ }^{81}$ The Lau Court upheld Regulation $A$ as a rational clarification of the statute without addressing whether the language or legislative history of Title VI mandates-or even permits-HEW's "effect test" or its affirmative remedies. ${ }^{82}$ The Court's reliance on the regulation alone is especially problematic in view of its possible subsequent repudiation in Regents of the University of California v. Bakke. ${ }^{83}$

78 Id. 566.

7945 C.F.R. $\S 80.3$ (b)(2) (1978).

80 May 25, 1970 Memorandum from the Director, Office for Civil Rights, HEW, to School Districts with More than Five Percent National Origin-Minority Group Children, 35 Fed. Reg. 11, 595 (1970) [hereinafter cited as 1970 Memorandum].

$81 I d$.

82 Lau v. Nichols, 414 U.S. 563, 568 (1974).

83438 U.S. 265 (1978). Justice Brennan suggests that Regents of the Univ. of Cal. v. Bakke, id., is inconsistent with Lau v. Nichols, 414 U.S. 563 (1974), that the latter case seemed to imply that Title VI, $\S 601,42$ U.S.C. $\$ 2000 \mathrm{~d}$ (1976), prohibitions were more stringent than those of the Constitution. 438 U.S. at 352 (Brennan, J., concurring in the judgment in part \& dissenting in part). HEW's interpretation should, however, have at least some advisory force. See note 68 supra \& accompanying text. 
The brief Lau opinion left open many fundamental questions regarding both the scope and the legal basis of a school district's duty. Three principal areas are particularly troublesome. First, by focusing upon the denial of "any meaningful education" to nonEnglish speaking students, the Court avoided deciding what degree of deprivation triggers a Title VI violation. Second, Lau raised the possibility that Title VI applies only when large numbers of students are deprived and perhaps not in the case of a single nonEnglish speaking student. Third, the Court did not explore the types of programs able to provide an effective remedy.

\section{a. Denial of "any meaningful education"}

By emphasizing the complete inability of non-English speaking Ghinese students to compete in the educational system in Lau $v$. Nichols, ${ }^{84}$ the Court did not decide whether a total deprivation of education was required to make out a Title VI ${ }^{85}$ violation. Minority students have widely varying degrees of language skills, and designing a curriculum sensitive to each gradation might require numerous types of remedial programs. In 1975, HEW attempted to clarify Regulation $\mathrm{A}^{86}$ and Lau by defining those students entitled to remedial education as those either monolingual in a language other than English or dominant in such a language. ${ }^{87}$ Because the second category of students does not experience a total deprivation with English language instruction, HEW has seemingly extended Lau to require a substantial degree of English language comprehension before monolingual language instruction will suffice.

\section{b. Application of Title VI to Small Numbers of Students}

Perhaps the most vexing problems posed by Lau $v$. Nichols $8 \delta$ stem from the concurrence of Justice Blackmun, joined by Chief Justice Burger. For Justice Blackmun, "numbers [were] at the heart of this case." ${ }^{89}$ Although this notion was left undeveloped in his opinion, Justice Blackmun's central concern appears to have

84414 U.S. 563 (1974).

85 Section 601, 42 U.S.C. $\$ 2000 d$ (1976).

8645 C.F.R. $\$ 80.3(\mathrm{~b})(2)(1978)$.

$87 \mathrm{HEW}$ Task Force Findings Specifying Remedies Available for Eliminating Past Educational Practices Ruled Unlawful Under Lau v. Nichols 9-12 (Aug. 11, 1975), reprinted in CENTER FOR LAW and EDUCATION, BuldNGUAL-Bicultural EduCATroN (1975) [hereinafter cited as HEW Task Force Findings].

88414 U.S. 563 (1974).

89 Id. 572 (Blackmun, J., concurring). 
been the difficulty and cost of providing compensatory education when only a few students are linguistically disadvantaged. Arguably, a school district has no obligation to devote a disproportionately high percentage of its resources to a small number of children. ${ }^{90}$ A resulting reduction in the quality of education for the majority might constitute a sufficiently compelling justification for a district's failure to provide such a costly program for the minority. In addition, a child entering a school as one of a small linguistic minority is far less likely to live in an isolated neighborhood or community. His exposure to English outside of school might well overcome any language barrier. ${ }^{91}$

A cultural monist would probably agree with Justice Blackmun's concern with "numbers": reinforcing cultural identity is perhaps appropriate when large numbers of minority members live together, but not when the minority child is living in a majority community. The child in the latter situation will blend into and be accepted by the community by learning and adopting the cultural norms of the majority. ${ }^{22}$

Upon close examination, however, Justice Blackmun's position is untenable. Title VI ${ }^{93}$ is meant to insure that federal funds are spent to aid minorities as well as Anglos. The literal language of the statute is seemingly unconcerned with quantification of the deprivation, but instead reads, "[n]o person shall . . . be subjected to discrimination." 94 In addition, Title VI simply restricts the spending of supplemental federal funds. If a school district feels financially overburdened by bilingual education requirements, it can simply refuse the federal funds and thereby free itself of the statute's restrictions. ${ }^{95}$

Finally, regardless of the number of minority children in a district, depriving any child of an education creates a harm for the

90 Serna v. Portales Municipal Schools, 499 F.2d 1147, 1154 (10th Cir. 1974); Otero v. Mesa County Valley School Dist. No. 51, 408 F. Supp. 162, 169 (D. Colo. 1975), vacated and remanded on other grounds, 568 F.2d 1312 (10th Cir. 1978). isolation.

91 Even a small number of minority peers may, however, encourage linguistic

In areas populated by only a few minorities, a pluralist model, as defined by Kjolseth, see note 21 supra, would be particularly difficult to implement because its goal is the use of two languages in community activities. Search for less costly alternatives to bilingual education is particularly appropriate, therefore, when bilingual classes would have only few non-English speaking students. barriers.

${ }^{92}$ Assimilation may well prove difficult, however, if impeded by language

93 Section 601, 42 U.S.C. $\$ 2000 \mathrm{~d}$ (1976).

94 Section 601,42 U.S.C. $\$ 2000 \mathrm{~d}$ (1976).

95 Id. $\$ 2000 \mathrm{~d}-1$. 
individual the ramifications of which may well extend throughout his life. In fact, in a community with few minorities, denying an education to a minority child arguably produces more serious psychological damage because his competency in a foreign language is of little comfort when he has no peers with whom to communicate. Educating those children might thus be more important than providing additional education to a greater number of Anglos. The HEW Task Force, ${ }^{96}$ perhaps having made that value judgment, has declared that Title VI is applicable to individual cases: "a district does have an obligation to serve any student whose primary or home language is other than English." 97

The cultural pluralist would agree that linguistic and cultural reinforcement is especially critical for isolated children. If society is to be enriched by variations in traditions and values, minorities must maintain their cultures and languages. In a community with little minority representation, special effort is necessary to preserve and develop these cultures and Anglo contact with them.

\section{c. Remedies}

An additional problem with applying Lau $v$. Nichols ${ }^{98}$ is the generality of the discussion of remedies. The Court simply said:

No specific remedy is urged upon us. Teaching English to the students of Chinese ancestry who do not speak the language is one choice. Giving instructions to this group in Chinese is another. There may be others. Petitioners ask only that the Board of Education be directed to apply its expertise to the problem and rectify the situation. ${ }^{99}$

Although leaving the choice of remedy to the school district's discretion temporarily restricts the necessary judicial intervention, school districts and lower courts are left with little guidance regarding which remedies are sufficient both to meet the linguistic needs of students and to comply with all legal requirements. The Tenth Gircuit has read Lau as requiring bilingual-bicultural education, ${ }^{100}$ while the Ninth has held that other types of remedial programs may satisfy a district's Title VI obligations. ${ }^{101}$

96 HEW Task Force Findings, supra note 87.

97 Id. 4.

98414 U.S. 563 (1974).

99 Id. 564-65.

100 Serna v. Portales Munic. Schools, 499 F.2d 1147, 1154 (10th Cir. 1974).

101 Guadalupe Org., Inc. v. Tempe Elem. School Dist. No. 3, 587 F.2d 1022, 1029-30 (9th Cir. 1978). 
HEW has not been as deferential to school board preferences. The agency requires a bilingual program or its equivalent-perhaps an individual tutorial program-in all school districts with linguistic minority school children.102 HEW's 1975 Task Force Findings set forth several alternatives: a Transitional Bilingual Education Program; a Bilingual/Bicultural Program; and a Multilingual/Multicultural Program. ${ }^{103}$

The Transitional Bilingual Education Program (TBE) and the Bilingual/Bicultural Program are very similar except that, under the former, a student is no longer entitled to further instruction in his native language once he is fully proficient in English. The Bilingual/Bicultural Program, on the contrary, is a maintenance model, continuing to develop skills in the student's native language and culture in addition to teaching English. The program's goal is proficiency in both languages. The Multilingual/ Multicultural Program is identical to the Bilingual/Bicultural Program except that the former teaches more than one language, in addition to English.

All three programs include a cultural component, "introducing, maintaining, and developing all the necessary skills" 104 in both language and culture. ${ }^{105}$ HEW's requirement that the minority culture be maintained and developed is a major extension of Lau, which spoke only of linguistic obstacles to learning. The agency's attitude toward the cultural component is unclearwhether it is necessary for effective education or simply a helpful addition to a bilingual program. This aspect of the programs is extremely controversial because it strengthens cultural differences and thereby discourages the adoption of Anglo cultural norms. ${ }^{108}$

A school district's choice between maintenance and transition models is likely to be influenced by its social values. ${ }^{107}$ A district adhering to a pluralistic view of integration and hoping to foster mutual appreciation among groups by exposing each group to the

102 The Ninth Circuit surprisingly made no reference to the HEW Task Force Findings, supra note 87 , in Guadalupe Org., Inc. v. Tempe Elem. School Dist. No. 3, 587 F.2d 1022 (9th Cir. 1978).

103 HEW Task Force Findings, supra note 87, at 6.

104 Id. 21.

105 For summary descriptions of the three programs, see $i d$.

106 The cultural aspect of bilingual programs often attracts English speaking minority students to the program. See text accompanying notes 191-94 infra. Congress has included a cultural component in federally funded bilingual programs. See Bilingual Education Act, $\$ \S 701-751,20$ U.S.C. $\$ \$ 3221-3261$ (Supp. 1979); [1974] U.S. Code Cong. \& AD. News 4148.

107 See notes 11-28 supra \& accompanying text. 
culture of the other will tend to favor a maintenance model. Maintenance models are also most effective in preserving minority cultural norms and teaching multiple language skills to both minority and majority students. ${ }^{108}$ On the other hand, a school board advocating cultural monism will hurry to return minority children to a monolingual class as quickly as possible ${ }^{100}$ and will be disinclined to accept a bilingual program designed to teach a new language and culture to Anglo students. HEW's acceptance of both models allows school districts the choice according to their own values. ${ }^{110}$

The scope of a school district's choice of remedies is thus unclear-HEW requires some form of bilingual-bicultural education, while Lau arguably affords greater discretion to the individual districts.

\section{The Equal Educational Opportunity Act of 1974}

Although Title VI ${ }^{111}$ may not have been intended to require school districts to remedy those disparate impacts of its educational system not caused by deliberate design, ${ }^{112}$ Congress quickly affirmed its support for Lau $v$. Nichols 113 by enacting section 1703(f) of the Equal Educational Opportunity Act of 1974.114 The Act requires school districts "to take appropriate action to overcome language barriers that impede equal participation by its students in its instructional programs." 115 The language of the Act thus explicitly mandates remedial assistance to students of limited English speaking ability, even when their need for such assistance is not the result of intentional discrimination. ${ }^{118}$

108 See notes 21-22 supra \& accompanying text.

109 See note 13 supra \& accompanying text.

$110 \mathrm{HEW}$ does not, however, regard their acceptance of the TBE model as an implicit authorization of segregation:

The implementation of the aforementioned educational models do not justify the existence of racially/ethnically isolated or identifiable classes, per se. Since there is no conflict in this area as related to the application of the Emergency School Aid Act (ESAA) and existing Title VI regulations, standard application of those regulations is effective.

HEW Task Force Findings, supra note 87, at 18. For a further discussion of the requirement that bilingual classes be integrated, see notes 150-213 infra \& accompanying text.

111 Section 601, 42 U.S.C. $\$ 2000$ d (1976).

112 See notes 67-68 supra \& accompanying text.

113414 U.S. 563 (1974).

114 Section 204, 20 U.S.C. $\$ 1703(f)$ (1978). The Act provides: "No State shall deny equal educational opportunity to an individual on account of his or her race, color, sex, or national origin ...." Id. § 1703.

115 Id. $\$ 1703(f)$.

116 Two courts have thus held that the prohibitions of the Equal Education Opportunity Act of 1974, $\$ \$ 202-223,20$ U.S.C. $\$ \S 1701-1721$ (1978), go beyond 
Just as Title VI and Lau left remedial choices to the discretion of the school district, ${ }^{117}$ so too section $1703(\mathfrak{f})$ does not indicate what constitutes "appropriate action." The Ninth Circuit held in Guadalupe Organization, Inc. v. Tempe Elementary School District No. $3^{118}$ that programs not offering bilingual-bicultural education may be sufficient to satisfy the statute's requirements. Absent clear legislative intent to limit school board flexibility to experiment with new programs, Guadalupe is correct. Like Title VI, however, section 1703 (f) does not resolve questions of effectiveness of remedies, ${ }^{119}$ applicability to small numbers of students, ${ }^{120}$ and required degree of English language proficiency. Although the same policy considerations discussed above with regard to Title VI also apply here, HEW does not have explicit authority to enforce

those of the Constitution. United States v. Hinds County School Board, 560 F.2d 619, 623-24 (5th Cir. 1977); Martin Luther King Elem. School Children v. Michigan Bd. of Educ., 463 F. Supp. 1027, 1031-32 (E.D. Mich. 1978); see Deerfield Hutterian Ass'n v. Ipswich Bd. of Educ., 444 F. Supp. 159, 163 (D.S.D. 1978). The court in Martin Luther King based its finding that discriminatory intent is not a necessary element of a $\$ 1703(f)$ violation in part on Title VI, $\$ 601,42$ U.S.C. $\$ 2000 d$ (1976), and on Lau v. Nichols, 414 U.S. 563 (1974), a questionable conclusion after Regents of the Univ. of Cal. v. Bakke, 438 U.S. 265 (1978). See note 83 \& text accompanying note 63 supra. Following Bakke, however, a subsequent decision in Martin Luther King found a $\$ 1703(f)$ violation despite absence of discriminatory motive and constitutional violation. Martin Luther King Elem. School Children v. Michigan Bd. of Educ., No. 7-71861 (E.D. Mich. July 12, 1979). This district court obviously feels that, despite the comparison between $\$ 1703$ and Title VI in the earlier opinion, the Equal Education Opportunity Act of 1974 does impose more stringent restrictions than does the Constitution.

Although the Supreme Court has recently been reluctant to find discrimination in the absence of improper motives, see note 60 supra \& accompanying text, this measure was passed with a striking absence of controversy. The Equal Educational Opportunity Act of 1974,20 U.S.C. $\$ \$ 1701-1721$ (1978), was introduced during floor debate as an amendment to the Education Act of 1974. 120 Conc. Rec. 14812 (1974); see also Guadalupe Org., Inc. v. Tempe Elem. School Dist. No. 3, 587 F.2d 1022, 1030 (9th Cir. 1978). Congress was concerned chiefly with the portion of those amendments limiting transportation of students to achieve racial balance. Section 1703(f), however, remained unnoticed. In accepting $\S 1703$ (f) under the rubric of equal educational opportunity, Congress apparently endorsed the implication in Lau v. Nichols, 414 U.S. 563 (1974), that equal rights for minorities requires remedial education. Senator Montoya, one of the sponsors of the 1974 amendment, commented, "[s]o we know now [after Lau], that the civil rights of these minority children are involved." 120 CoNG. Rec. 15090 (1974).

117 See notes 98-99 supra \& accompanying text.

118587 F.2d 1022 (9th Cir.) (1978).

119 One court has indicated that a remedial program under 20 U.S.C. $\S 1703(f)$ (1978) must include subject matter as well as language instruction. Cintron v. Brentwood Union Free School Dist., 455 F. Supp. 57, 63 (E.D.N.Y. 1978). See also note 71 supra.

120 The Sixth Circuit has held that the statute is violated if even one person is denied an equal education opportunity. United States v. School Dist. of Ferndale, 577 F.2d 1339, 1345 (6th Cir. 1978). 
section $1703(\mathfrak{f})$, and their regulations requiring bilingual education ${ }^{121}$ thus carry no great weight in interpreting that provision.

Although Lau reads Title VI as requiring remedial education for linguistic minorities, the scope and form of that duty must still be clarified. HEW has ordered some type of bilingual-bicultural education even when the number of students affected is not great and the deprivation of education not complete. The federal courts, on the other hand, have not been so strict in applying Title VI, and, after Regents of the University of California v. Bakke, ${ }_{0}^{122}$ the impact of the statute may be no different from that of the Constitution. Section $I 703(f)$, on the other hand, extends beyond the Constitution, though the scope of the duty it imposes to provide bilingual education is also unclear.

\section{B. The Constitutional Requirements}

Because the Supreme Court relied exclusively in Lau $\boldsymbol{v}$. Nichols ${ }^{123}$ on Title VI ${ }^{124}$ to require remedial programs for nonEnglish speaking students, ${ }^{125}$ it had no need to determine whether the Constitution also mandates remedial education. The merits of two possible constitutional arguments will be explored in the following discussion. The first has been rejected by two federal courts; ${ }^{120}$ nevertheless, a school district's choice of a program of instruction sensitive to the needs of only English speaking students is arguably discriminatory and subject to an equal protection attack. Second, such a choice may result in an unconstitutional denial of education to a segment of the student population. The following discussion explores the merits of both arguments.

The equal protection attacks on desegregation ${ }^{127}$ provide an appropriate starting point to evaluate the potentially discriminatory practice of teaching non-English speaking students only in English. Where segregation is not the result of facially discriminatory classifications, a strict standard of judicial review is triggered only if plaintiffs demonstrate intent by the state to segregate a suspect

121 HEW Task Force Findings, supra note 87. See notes 86-87, 96-97, 102-06 supra \& accompanying text.

122438 U.S. 265 (1978).

123414 U.S. 563 (1974).

124 Section 601, 42 U.S.C. $\$ 2000$ d (1976).

125 See notes 77-82 supra \& accompanying text.

126 Guadalupe Org., Inc. v. Tempe Elem. School Dist. Ǹo. 3, 587 F.2d 1022 (9th Cir. 1978); Keyes v. School Dist. No. 1, 521 F.2d 465, 482-83 (1975), cert. denied, 423 U.S. 1066 (1976).

127 See notes 55-64 supra \& accompanying text. 
class. ${ }^{128}$ The Supreme Court appears to favor extending to ethnic minorities the suspect class status traditionally applied to racial minorities. ${ }^{129}$ Linguistically disadvantaged minority students are thus entitled to maximum protection under the equal protection clause. Before this protection can be invoked to attack a school district's decision to teach classes only in English, however, the plaintiffs must prove preliminarily that the decision creates a classification at all.

A state offering all students the same instruction does not appear to be classifying students. The absence of an overt classification should not, however, end the inquiry. Just as classifications can be based on irrelevant characteristics, so services can be shaped unnecessarily to the detriment of one of the recipient groups. The equal protection clause may properly be applied to scrutinize a state's choice of a program tailored to meet the needs of only the majority. ${ }^{130}$ A school district's choice to offer instruction only in English to all students required to attend public school is a selection among the various alternative forms of education. This selection is the functional equivalent of a nonfacial discriminatory classification and should thus be subjected to equal protection analysis. ${ }^{131}$

128 See note 60 supra \& accompanying text.

129 In Hernandez v. Texas, 347 U.S. 475 (1954), the Supreme Court held that Mexican-Americans constitute an identifiable class for purposes of analysis under the fourteenth amendment. See United States v. Texas, 342 F. Supp. 24, 26-27 (E.D. Tex. 1971), aff'd, 466 F.2d 518 (5th Cir. 1972). For an extended discussion of the argument that linguistic minorities are a suspect class, see Comment, The Constitutional Right of Bilingual Children to an Equal Education Opportunity, 47 S. CAI. L. REv. 943, 979-85 (1974). But cf. Martin Luther King Elem. School Children v. Michigan Bd. of Educ., 451 F. Supp. 1324, 1328 (E.D. Mich. 1978) (plaintiffs, though all black, not suspect class because characteristics involved-cultural, economic, and social deprivation-are not suspect).

130 This analysis is distinct from the usual effects analysis, rejected in Washington v. Davis, 426 U.S. 229 (1976). There, the objective benefit given to one group, employment in the police force, was denied to another. The analysis proposed here is to be used when the objective benefits given to all are identical. See Grubb, Breaking the Language Barrier: The Right to Bilingual Education, 9 HaRv. C.R.-C.L. L. Ruev. 52, 71-81 (1974).

131 Suppose, for example, that a town, wishing to install street curbs to protect pedestrians from cars, had the option of building high or low curbs. The former would provide a barrier to handicapped persons, the latter would not. The choice of high curbs would be a selection. All persons would theoretically receive the same objective benefits of curbs, but, in reality, only non-handicapped individuals would be able to use them. Recognition that a state can discriminate by its choice of services as well as by its classifications of recipients of those services would have led to a different analysis in Guadalupe Org., Inc. v. Tempe Elem. School Dist. No. 3, 587 F.2d 1022 (9th Cir. 1978). In examining the claim that bilingual education is required by the equal protection clause, see notes 14-15 supra \& accompanying text, the court there employed the lowest level of scrutiny, the rational relation test, and upheld the school's remedial programs. Citing San An- 
Proving a discriminatory motive for this classification is a much more formidable obstacle. Under Washington $v$. Davis, ${ }^{\mathbf{1 3 2}}$ a plaintiff must demonstrate that the school district intended to treat majority and minority groups differently and provided services in a manner designed to exclude minorities. In the ordinary case, however, the possibility of success is rather slim. Use of English likely reflects to a large extent a long-standing national desire to use a common language without any discriminatory intent. ${ }^{133}$ Refusal to alter established practices to meet the particular needs of minorities is not itself indicative of discriminatory intent. ${ }^{134}$

The strongest case for linguistically disadvantaged plaintiffs would occur if a school board refused to provide instruction in a language other than English because of a desire not to teach minority students. Racial or ethnic animus is an improper motive for any state action. ${ }^{135}$ More difficult problems of proof would arise if, in anticipation of non-English speaking students entering the district, a school board ordered that instruction be in English. This action, a deliberate selection of a program beneficial to only a segment of

tonio Indep. School District v. Rodriguez, 411 U.S. 1 (1973), the Ninth Circuit held that a rational relation to a legitimate state interest is absent only when a school board completely denies the opportunity to learn basic skills. Guadalupe Org., Inc., 587 F.2d at 1026.

The court refused to invoke the strict scrutiny standard because no suspect classification existed: "[i]nasmuch as appellees only differentiate explicitly among students with respect to the provisions of remedial English instruction, no such claim is possible." Id. 1022, 1026 n.3. The court found the strict scrutiny test inappropriate also because no fundamental right was involved. Id. 1026; see note 142 infra. The Guadalupe court implied that strict scrutiny would not be applied in the absence of some other classification; yet the court did recognize a selection in "[t]he decision of the appellees to offer the educational program attacked by appellants." Guadalupe Org., Inc., 587 F.2d at 1027. The court was apparently willing to scrutinize this selection and thus should not have excluded automatically the possibility of invoking strict scrutiny if discriminatory intent could have been shown. If the need for special protection of minorities is sufficient to trigger strict judicial scrutiny of a classification, the standard should be no less exacting for more subtle forms of discrimination.

132426 U.S. 229 (1976). See note 60 supra \& accompanying text.

133 This goal of having all children speak English is constitutionally permissible. Meyer v. Nebraska, 262 U.S. 390, 401 (1923).

134 See Guadalupe Org., Inc. v. Tempe Elem. School Dist. No. 3, 587 F.2d 1022, 1028-29 (9th Cir. 1978). Persistence in a neighborhood school policy, for example, is not necessarily indicative of improper motivation, even if neighborhood housing segregation leads to racial separation in schools. Dayton Bd. of Educ. v. Brinkman, 433 U.S. 406 (1977). But see Dayton Bd. of Educ. v. Brinkman, 47 U.S.L.W. 4944, 4947 (U.S. July 2, 1979) (No. 78-627) (use of optional attendance zones is at least perpetuation of dual school system and thus violation of affirmative duty to eradicate effects of past discrimination); note 136 infra \& accompanying text.

135 See, e.g., Washington v. Davis, 426 U.S. 229 (1976). 
the student population, would have the foreseeable effect of denying a meaningful education to minorities. The foreseeability of disparate impact is relevant evidence to prove forbidden purpose. ${ }^{136}$ The intent, however, might be not to harm minorities, but rather to ensure that a common language is spoken in the schools. If the action is timed to coincide with the arrival of a minority group, ethnic animus might thereby properly be inferred. ${ }^{137}$ In most circumstances, however, proving discriminatory intent will be an insurmountable obstacle.

If discriminatory intent is shown, courts will then invoke the strict scrutiny standard. The state will have the difficult burden of proving that using only English as the language of instruction bears a necessary relation to a compelling state interest. If the state asserts as a goal teaching English to all students, bilingual or tutorial programs could accomplish this while better helping students to learn other subject areas ${ }^{138}$ and while avoiding the feelings of inferiority generated in non-English speaking children from offering instruction only in English. ${ }^{139}$ Even if use of English for nonEnglish speaking students is rational in light of this goal, it is certainly not necessary to a compelling state interest.

A linguistically disadvantaged student may also want to argue that selection of a program of instruction only in English is unconstitutional as a complete denial of education to a segment of the student population. Some support for this argument may be found in the school finance case, San Antonio Independent School District $v$. Rodriguez..$^{140}$ Rodriguez involved a challenge to the use in Texas of local property taxes to finance public education. The plaintiffs claimed that the system discriminated against districts with small revenue bases because those districts had greater difficulty than richer districts in raising revenue. ${ }^{141}$ Although the Supreme Court held that education is not a fundamental constitutional

${ }^{136}$ Columbus Bd. of Educ. v. Penick, 47 U.S.I.W. 4924, 4928 (U.S. July 2, 1979) (No. 78-610). See note 194 infra. The foreseeability test should be an important one, given that the cases that established the intent requirement, e.g., Washington v. Davis, 426 U.S. 229 (1976), did not involve actions the segregative impact of which was inevitable.

137 See Village of Arlington Heights v. Metropolitan Housing Dev. Corp., 429 U.S. 252, 267 (1977).

138 See notes 47-54 supra \& accompanying text.

139 Serna v. Portales Municipal Schools, 499 F.2d 1147, 1150 (10th Cir. 1974).

140411 U.S. 1 (1973).

141 Id. 27. 
right, ${ }^{142}$ it left open the possibility that completely denying education to some children might be constitutionally impermissible. ${ }^{143}$

Placing linguistic minorities in classrooms in which English is the only language of instruction may constitute a total deprivation. In Lau v. Nichols, the Supreme Court found that non-English speaking students denied remedial instruction in English were "foreclosed from any meaningful education." 144 Here, however, the deprivation is not the result of less money or services devoted to the education of minority children, as was the case in Rodriguez. On the contrary, all students receive exactly the same objective benefits. The difference in students' abilities to understand English creates the inequality. Rodriguez, however, does not purport to define exclusively a total deprivation and therefore does not foreclose the possibility that an unconstitutional absolute denial may result from such subjective differences. ${ }^{145}$

$142 \mathrm{Id}$. 35. Following this decision, the Ninth Circuit refused to recognize a fundamental right to education and therefore to apply a strict scrutiny standard in Guadalupe Org., Inc. v. Tempe Elem. School Dist. No. 3, 587 F.2d 1022, 1027 (9th Cir. 1978).

143 San Antonio Indep. School Dist. v. Rodriguez, 411 U.S. 1, 36-37 (1973). The Court applied a rational relation test in examining differences in educational benefits, $i d$. 40 , and held that the Texas legislature could rationally decide to base school financing on local property taxes, even if the result was disparities among school districts in educational resources. Id. 54-55. The Court did not purport, however, to deal with the situation of "an absolute denial of educational opportunities." Id. 37. For an extended analysis of the implications of Rodriguez, see Foster, supra note 11 , at 158.

144414 U.S. 563, 566 (1974). Although the Court did not reach the constitutional issue, its finding that plaintiffs were denied any meaningful education is relevant to the constitutional question of defining a total deprivation.

145 Perhaps the closest the Supreme Court has come to mandating subjectively equal services is in the criminal procedure area. For example, appellants unable to afford a transcript for appeal may have the cost defrayed by the state. Griffin v. Illinois, 351 U.S. 12 (1956); see Boddie v. Connecticut, 401 U.S. 371 (1971); Douglas v. California, 372 U.S. 353 (1963). Just as the state must provide special financing to open its appellate system to those otherwise denied access, so it arguably must provide a special program to open its educational system to those otherwise denied access. The Supreme Court has recognized the importance of education, San Antonio Indep. School Dist. v. Rodriguez, 411 U.S. 1, 35 (1973); Brown v. Board of Education, 347 U.S. 483, 493 (1954), and perhaps subjective differences among pupils as well as defendants should be taken into account.

On the other hand, this case does differ from Griffin. First, the government was acting in Griffin to deprive the defendant of liberty. Although minority schoolchildren are seriously affected by inadequate education services, see notes 179-83 infra \& accompanying text, the magnitude of the two harms is arguably different.

Second, the criminal defendants in Griffin were unable to obtain a benefitthe appeal-because of a financial barrier. Once an appeal without cost was permitted, the objective services given rich and poor defendants were identical. In this case minority children are unable to obtain a benefit because of a language barrier. In remedying the linguistic obstacle, the entire educational benefit must be reshaped-the objective services required are different. A considerable extension of Griffin is thus necessary to create a right to compensatory education. 
Even if non-English speaking students are able to show that teaching only in English unconstitutionally deprives them of a meaningful education, they must still demonstrate the appropriateness of the requested remedy. The "but for" requirement of Dayton Board of Education v. Brinkman ${ }^{146}$ creates problems of proof for plaintiffs in all cases, but ascertaining how a school district would be operating absent a constitutional violation is especially difficult in those involving non-English speaking students. Suppose, for example, an expensive tutorial program were rejected because school board members did not wish to educate non-English speaking students, a clear case of ethnic animus. Absent this discriminatory intent, the plan would likely have been rejected nonetheless because of its expense. A district court is not empowered to order that such a program be implemented, nor may it design a program of its own. ${ }^{147}$ The hypothetical "but for" situation is a matter of conjecture in the desegregation cases; when failure to institute a bilingual program is the source of the discrimination, judicial reasoning must be even more clairvoyant. ${ }^{148}$

Although HEW has imposed a duty under Title VI to provide bilingual-bicultural education, that requirement is suspect given Regents of the University of California $v$. Bakke, ${ }^{149}$ and the Constitution may not afford any better claim for relief by linguistic minorities. An equal protection challenge will likely encounter insuperable problems in proving discriminatory intent, though, if that burden is met, the school district will have difficulty justifying the discrimination. Minority students may be more successful in arguing an unconstitutional deprivation of education. Though Rodriguez arguably leaves open the issue, the courts will have to recognize a duty on the part of the school districts to provide some education and, correspondingly, the right of citizens to demand education. Then "but for" problems may arise if the requested relief would have been denied even absent the constitutional violation.

146433 U.S. 406 (1977). See notes 62-64 supra \& accompanying text.

${ }^{147}$ A minority group which suspects its proposal will be rejected for constitutionally impermissible reasons is thus faced with a tactical dilemma. It could, on the one hand, ask for the most feasible program it would find acceptable. If this plan were then rejected for an impermissible reason, a district court would have power to give the minority group the requested relief. If, on the other hand, the group sought too much, showing that the improper motivation was the "but for" cause of the plan's rejection would be difficult.

148 See notes 64 supra \& accompanying text.

149438 U.S. 265 (1978). 
V. The Duty to Integrate Bilingual Classrooms

The constitutional duty not to separate students deliberately and the duty imposed by HEW to provide bilingual education ${ }^{150}$ have had dramatic impact on the structure of educational services; a requirement that bilingual classes be integrated would, however, necessitate additional readjustment. The lack of clarity in the statutes and HEW regulations concerning this important issue, perhaps due to its political volatility, has focused attention on constitutional requirements. Just as desegregation and bilingual education plans lay dormant until sparked by Supreme Court mandates, so integrated bilingual education may occur only if ordered by the Court.

\section{A. The Statutes}

The federal statutes do not clearly address the issue of integration of bilingual education. The Bilingual Education Act ${ }^{151}$ permits inclusion of Anglos in bilingual programs, though they may not constitute greater than forty percent of the class. ${ }^{152}$ The Act does not, however, seem to require this integration.

Title VI leaves undefined the term "discrimination," ${ }^{153}$ perhaps the key word in the statute. Moreover, that statute is unclear whether individuals are "excluded from" 154 a program when they participate in a separate, optional program. The very issue here is whether a separate program "discriminates."

Although the Equal Educational Opportunity Act of $1974{ }^{155}$ provides that " $[\mathrm{n}] \mathrm{o}$ State shall deny equal education opportunity ... by ... the failure by an educational agency to take appropriate action to overcome language barriers that impede equal participation by its students in its instructional programs," 156 the Act does not define the parameters of "appropriate action." The statutes thus require remedial programs, but provide no indication of congressional intent regarding the appropriate racial composition of the bilingual classroom.

\section{B. HEW Regulations}

The HEW regulations, providing no more guidance than do the applicable statutes, can only be described as inconclusive. Pro-

150 See notes 102-10 supra \& accompanying text.

151 Sections 701-751, 20 U.S.C. $\$ \$ 3221-3261$ (Supp. 1979).

152 Id. $\$ 3223(\mathrm{a})(4)(\mathrm{B})$.

153 Section 601, 42 U.S.C. $\$ 2000 \mathrm{~d}$ (1976).

$154 I d$.

165 Sections 201-223, 20 U.S.C. $\$ \$ 1701-1721$ (1978).

$166 \mathrm{Id} . \S \S 1703,1703$ (f). 
mulgated under the Bilingual Education Act, ${ }^{157}$ the Emergency School Aid Act, ${ }^{158}$ and Title VI, ${ }^{159}$ the regulations decide the issue in all possible ways, leaving a school board unable to decipher their true meaning. By complying with one regulation, a school district is vulnerable to termination of its funds pursuant to another regulation. The dilemma is truly preplexing.

The regulations promulgated under the Bilingual Education Act give a district the option of including Anglos if space is available and if they wish to be included. One such regulation reads:

A program of bilingual education may make provision for the voluntary enrollment to a limited degree therein, on a regular basis, of children of other than limited Englishspeaking ability, in order that they may acquire an understanding of the cultural heritage of the children of limited English-speaking ability for whom the particular program of bilingual education is designed. In determining eligibility to participate in such programs, priority shall be given to children of limited English-speaking ability. In no event shall the program be designed for the purpose of teaching a foreign language to English-speaking children. ${ }^{160}$

This regulation clearly leaves Anglo participation in federally funded bilingual education to the discretion of the district and thus permits segregated bilingual programs.

The regulations pursuant to the Emergency School Aid Act (ESAA) take a contrary approach. Classroom segregation of minority students for more than twenty-five percent of the day is prohibited, ${ }^{161}$ thereby invalidating most segregated bilingual programs. Although an exemption is provided for "bona fide ability grouping," 162 the exemption covers only groupings "which, in the case of national origin minority group children, do not essentially measure English language skills." ${ }^{163}$ Moreover, the regulations explicitly prohibit discrimination on the basis of language or cultural background. ${ }^{164}$ Although this prohibition can be read to bar only classes not specially sensitive to the language needs of students, another subsection of this regulation creates a presumption that

157 Sections 701-751, 20 U.S.C. $\$ \$ 3221-3261$ (Supp. 1979).

158 Sections 601-617, 20 U.S.C. $\$ \oint 3191-3207$ (Supp. 1979).

159 Section 601, 42 U.S.C. $\$ 2000$ (d) (1976).

16045 C.F.R. $\$ 123.02$ (g)(2)(i) (1978).

16145 C.F.R. $\$ 185.43$ (c) (1977).

$182 I d$.

163 Id. $\$ 185.43$ (c) (1).

164 Id. $\S 185.43(\mathrm{~d})(2)$. 
racially identifiable classes not justifiable as bona fide ability groupings are assignments on the basis of race, color, or national origin..$^{165}$ ESAA thus prohibits segregated bilingual education..$^{166}$

Title VI regulations provide no answer to this conflict. Instead, they simply increase the risk-a Title VI violation may result in termination of all federal funds. ${ }^{167}$ The regulations do not indicate whether classrooms segregated for bilingual purposes have the "effect of subjecting individuals to discrimination" 168 or impermissibly exclude persons. ${ }^{169}$ The clarifying memorandum, focusing on the discriminatory effect of heterogeneous classrooms with instruction only in English, ${ }^{170}$ provides no aid in determining the legality of segregated bilingual classrooms. The answer to whether bilingual classrooms must be integrated must therefore be found in some other source.

\section{Constitutional Considerations}

A fourteenth amendment violation will more likely be found when students are segregated for purposes of bilingual education than when they are taught in an integrated environment. Racially identifiable bilingual classrooms manifestly classify and separate minorities, and their constitutionality may well depend on the type of bilingual program and on the characteristics or allegations of the plaintiff students. In most cases, however, plaintiffs will at least

$165 I d . \$ 185.43(\mathrm{~d})(5)$.

166 The Office of Civil Rights (OCR) has so interpreted the ESAA regulations: "[HEW's] policy, then, as expressed in the ESAA regulations it has promulgated, is that ESAA prohibits the racial or ethnic isolation or segregation of children on the basis of English language ability for any substantial portion of the school day," that is, more than twenty-five percent of the day. Memorandum on Desegregation and Isolation of Minorities from P. Jacobo, Assistant Regional Attorney, Region VI, OCR, to Lau Task Force Members (Apr. 3, 1975). A dispute over racially identifiable classrooms in La Junta, Colorado, prompted an OCR investigation. Finding a substandard program in operation, OCR properly denied ESAA funding on that basis, without reaching the segregation issue. Letter from $\mathrm{H}$. Goldberg, Associate Commissioner of Education, to S. Roberts, Superintendent of Schools (June 21, 1977). Recently OCR alleged that the La Junta program violated Title VI, $\$ 601,42$ U.S.C. $\S 2000 \mathrm{~d}$ (1976), because of program deficiencies. Notice of Opportunity for Hearing, East Otero School Dist. No. R-1, Dept. of HEW Docket No. 79-VI-5 (June 25, 1979). Moreover, the allegations reiterated OCR's position that substantial segregation is not permissible: the district was cited for failing to assign minority students on the basis of bona fide ability groupings, $i d$. 9 , and for discouraging nonminority enrollment, id. 12. Because the district is operating an optional program open to all students, the OCR position strikes the proper policy balance. See notes 189-213 infra \& accompanying text.

167 Section 602, 42 U.S.C. $\$ 2000$ d-1 (1976).

168 Regulation A, 45 C.F.R. $\$ 803(\mathrm{~b})(2)$ (1978). See text accompanying note 66 supra.

169 Title VI, $\$ 601,42$ U.S.C. $\$ 2000$ d (1976). See note 65 supra.

1701970 Memorandum, supra note 80. 
be able to demonstrate the first essential element of a prima facie case, a deliberate classification according to minority status. ${ }^{171}$

\section{Mandatory Bilingual Programs Limited to Minority Students}

The most extreme type of bilingual program would segregate non-English speaking minority students by force of law. Although no program currently in operation requires minority attendance, ${ }^{172}$ examination of such a program is important for analytic purposes.

If a school board forces non-English speaking minorities into separate classrooms, the facial nature of the classification and the resulting segregation would normally trigger strict judicial scrutiny. ${ }^{173}$ A bilingual program designed to correct the inequality existing in monolingual classrooms may arguably be entitled, however, to a less exacting standard because of its remedial purpose. Four Justices accepted a similar argument in Regents of the University of California v. Bakke ${ }^{174}$ and thus employed an intermediate level test in examining the school's admissions policy of reserving spaces for minority applicants. The Justices thus required the challenged policy to "serve important government objectives and [to] be substantially related to achievement of those objectives." "175

Even accepting the views of these Justices, forced separation of linguistically disadvantaged students warrants application of a strict standard of scrutiny. These students, in contrast to Bakke, are members of a suspect class and are therefore entitled to maximum protection under the equal protection clause. ${ }^{176}$ The immediate result of such a mandatory program is segregation, precisely the opposite effect of race conscious remedies. ${ }^{177}$

171 Cf. notes 130-32 supra \& accompanying text (offering instruction only in English as a classification). Desegregation must be accomplished in classrooms as well as schools. The harms of intentional state segregation are the same at both levels. The Supreme Court has supported this view by treating identically interdistrict and intradistrict segregation. See Milliken v. Bradley, 418 U.S. 717 (1974). The Fifth Circuit has specifically held that classroom racial segregation is proscribed. McNeal v. Tate County School Dist., 508 F.2d 1017, 1019 (5th Cir. 1975).

172 Some school districts may, however, have coerced minorities to enroll in bilingual programs through their administration of the program. See notes 191-94 infra \& accompanying text.

173 See notes 57-58 \& 129 supra \& accompanying text.

174438 U.S. 265 (1978).

$175 \mathrm{Id} .359$ (1978) (Brennan, J., concurring in the judgment in part and dissenting in part) (quoting Califano v. Webster, 430 U.S. 313, 317 (1977)). Justice Powell, however, would apply a strict level of scrutiny to all racial and ethnic classifications. Id. 291-99 (Powell, J.).

176 See note 129 supra \& accompanying text.

177 See, e.g., United Jewish Org. of Williamsburgh, Inc. v. Carey, 430 U.S. 144 (1977) (upholding race conscious reapportionment plan to enhance voting strength 
This separation creates harms of stigma and loss of contact with Anglo peers. ${ }^{178}$ Classification according to English language proficiency stigmatizes minority schoolchildren by implying that they cannot be taught in the same classrooms as English speaking students. ${ }^{179}$ The Court in Brown v. Board of Education found that school segregation "generates [in minority students] a feeling of inferiority as to their status in the community that may affect their hearts and minds in a way unlikely ever to be undone." 180 This effect is not mitigated even by providing superior services to the segregated minority group. ${ }^{181}$ Stigma may occur even in the absence of ethnic animus by the very perception of discriminatory intent. ${ }^{182}$ Separation may of minorities); Swann v. Charlotte-Mecklenburg Bd. of Educ., 402 U.S. 1 (197I) (ordering race conscious student assignment to integrate schools).

178 This loss of contact not only decreases cultural exchange but may also create adverse educational effects. See Goodman, De Facto School Segregation: A Constitutional and Empirical Analysis, 60 CAx. L. REv. 275, 400-35 (1972).

179 See Regents of the Univ. of Cal. v. Bakke, 438 U.S. 265, 360 (1978) (Brennan, J., concurring in the judgment in part and dissenting in part) (citation omitted) ("State programs designed ostensibly to ameliorate the effects of past racial discrimination obviously create the same hazard of stigma, since they may promote racial separatism and reinforce the views of those who believe that members of racial minorities are inherently incapable of succeeding on their own."). Segregated programs may also have a stigmatizing impact by implying that the cultural identity of a specially disadvantaged group cannot or should not be maintained in an integrated environment. Cultural Pluralism, supra note 10, at 144.

180347 U.S. 483, 494 (1954). Although non-English speaking children may not themselves feel as inferior as did the black students in Brown v. Board of Educ., $i d$., segregating the former does create the alienating perception that the government views them as inferior.

181 Brown v. Board of Educ., 347 U.S. 483 (1954), focused primarily on the harmful effects produced by separate educational facilities. The Court there compared the quality of education received in segregated black schools with that received in white schools. The general failure to evaluate possible adverse effects in cases after Brown may reflect a presumption that such harm exists. The Court has not hesitated, however, to examine alleged harmful effects in cases involving remedial programs. E.g., Regents of the Univ. of Cal. v. Bakke, 438 U.S. 265 (1978); United Jewish Org. of Williamsburgh, Inc. v. Carey, 430 U.S. 144 (1977); Swann v. Charlotte-Mecklenburg Bd. of Educ., 402 U.S. 1 (1971). See Goodman, supra note 179, at 295-98, 400-35 (1972); Note, Reading the Mind of the School Board: Segregative Intent and the De Facto/De Jure Distinction, 86 YALE L.J. 317, 346-49 (1976) [hereinafter cited as Reading the Mind of the School Board]. Cf. Ely, The Constitutionality of Reverse Racial Discrimination, 41 U. CHr. L. REv. 723 (1974) (advocating a less exacting standard of scrutiny when a minority is benefited rather than harmed). For the proposition that state action abridging constitutional provisions cannot be justified simply because it confers a benefit, see Goldberg v. Kelly, 397 U.S. 254 (1970); Van Alstyne, The Demise of the Right-Privilege Distinction in Constitutional Law, 81 HARv. L. Rev. 1439 (1968).

Although the Supreme Court has never specifically addressed this question, it has always mandated integration as part of segregation remedies. See, e.g., Brown v. Board of Educ. (Brown II), 349 U.S. 294 (1955); Milliken v. Bradley (Milliken II), 433 U.S. 267 (1977).

182 See Reading the Mind of the School Board, supra note 181, at 347-48. The perception may not, in fact, be far off the mark. See notes 191-94 infra \& accompanying text. 
be viewed as indicative of the school board's aversion to integration. Regardless of how courts treat claims of white students in situations involving integration efforts with no danger of these harms, claims of non-English speaking students are entitled to strict scrutiny. ${ }^{183}$

A bilingual program may survive this scrutiny if the state can successfully demonstrate a compelling state interest. Bilingual education aids students whose language prevents their meaningful participation in monolingual classrooms. Indeed, bilingual programs, by insuring that each student receives an education in a language he can understand, accord with the fourteenth amendment's emphasis on equality of treatment. Although the state may be able to prove a compelling interest, mandatory bilingual programs limited to non-English speaking students do have a less restrictive alternative-simply making the programs voluntary and integrated. ${ }^{184}$

Anglo students excluded from a segregated bilingual program may also allege a violation of their fourteenth amendment rights. These students are denied both the opportunity to associate with non-English speaking students and the linguistic and cultural benefits of a bilingual program. Justice Powell's opinion in Bakke ${ }^{185}$ suggests that any program excluding persons on the basis of race should be examined under the strict scrutiny test. ${ }^{186}$ Just as Bakke could not be excluded from a medical school simply because he was white, so perhaps Anglos may not be excluded from a bilingual program solely because they can speak English.

Although similar, Bakke's claim is more persuasive: exclusion from the special admissions program effectively denied him a place in medical school because he failed to qualify under the regular admissions program. Segregated bilingual programs, however, deny no one an education. ${ }^{187}$ English speaking students must simply

183 See Guey Heung Lee v. Johnson, 404 U.S. 1215, 1217 (Douglas, Circuit Justice, 1971) (quoting Johnson v. San Francisco Unified School Dist., 339 F. Supp. 1315, 1322 (N.D. Cal. 1971)) ("Bi-lingual classes are not proscribed. They may be provided in any manner which does not create, maintain or foster segregation.").

184 A voluntary bilingual program open only to non-English speaking students also has the same less restrictive alternative. For an analysis of the alternative, see notes 189-213 infra \& accompanying text.

185438 U.S. 265 (1978).

186 The precedential effect of Regents of the Univ. of Cal. v. Bakke, id., remains uncertain. No constitutional standard was approved by the entire Court: four Justices used an intermediate level of scrutiny, id. 359 (Brennan, $J$., concurring in the judgment in part and dissenting in part), Justice Powell applied a strict scrutiny test, id. 291-99 (Powell, J.), and the remaining members of the Court declined to address the constitutional issue, $i d$. 411-12 (Stevens, J., concurring in part and dissenting in part).

187 This distinction is of importance to Justice Powell. He regarded the racial classification in Regents of the Univ. of Cal. v. Bakke as suspect because it effectively 
attend monolingual classes. Though deprived of the extra linguistic and cultural exposure of the bilingual classroom, these students are affected less severely than was Bakke.

Furthermore, if the intermediate level of scrutiny applied by four Justices in Bakke ${ }^{188}$ prevails in suits brought by Anglos, the segregated bilingual programs might withstand constitutional challenge. Nevertheless, the educational and associational harms suffered by Anglo children should be sufficient to require a showing by the state of the unavailability of a less restrictive alternative. In any event, the likelihood of success of a constitutional challenge to mandatory bilingual programs open only to minority students is much greater if minority students are the plaintiffs.

\section{Optional Bilingual Programs Open to All Students}

A voluntary bilingual program open to all creates no facially invidious classification. Students are not forcibly separated either by their English language proficiency or by their ethnic minority status, but rather by their own choice. The individual choices of students or their parents might conceivably result in classrooms with compositions reflecting the school's ethnic distribution. If not, ${ }^{189}$ minority students could then allege that the separation violates the state's duty not to segregate ethnic minorities.

Unlike mandatory programs, optional programs that accept all students do not evince an intent to separate, in view of the classification's facially neutral appearance. ${ }^{190}$ By their very nature, of course, bilingual programs are designed with minorities in mind. The more difficult burden with regard to intent is showing that a school board purposefully designed or administered the program to separate non-English speaking students from Anglos.

Certain aspects of a bilingual program, such as its curriculum or methods of instruction, may reveal segregative intent. Because

excluded some individuals "from enjoyment of a state-provided benefit-admission to Medical School-they otherwise would receive." 438 U.S. 265, 305 (1978) (Powell, J.). Similarly, Justice Powell read Lau v. Nichols as turning on the denial of " a meaningful opportunity to participate in the educational program." "Id. 304 (quoting Lau v. Nichols, 414 U.S. 563, 568 (1974)). A high degree of deprivation might also be crucial to finding an equal protection violation under an intermediate level of scrutiny.

188 See notes 175-76 supra \& accompanying text.

189 The AIR Study reported a high percentage of minority students in bilingual classrooms. See notes 40 \& 45 supra \& accompanying text.

190 The discussion of discriminatory intent which follows arguably shows that such a classification is not facially neutral. In light of the absence of explicit ethnic criteria in the classification, the ethnic design of the programs is best discussed in the context of intent. See notes 60-64 supra \& accompanying text. 
bilingual programs are geared towards a minority language and culture ${ }^{191}$ in terms of teaching techniques as well as subjects of instruction, they create an environment familiar to minority students and somewhat similar to their home environments. This familiarity, plus peer and family pressure, may induce minority children to enroll in bilingual programs. If maintenance programs are included in the bilingual curriculum, students, even after becoming proficient in English, may not wish to transfer into monolingual classrooms. ${ }^{192}$ The incentive to enroll and remain in bilingual classes will be even more pronounced if no effort is made to adjust monolingual classrooms to the needs of minorities. While minority students are therefore attracted to bilingual programs, Anglos find them unfamiliar. ${ }^{193}$ Anglos may also be dissuaded from enrolling in a bilingual program for which foreign language proficiency is a prerequisite or which is depicted as a minority program rather than one of mutual enrichment. Discriminatory intent can thus be inferred if a school seems deliberately to have made a voluntary bilingual program unattractive to Anglos and, correspondingly, to have left minorities with little choice but to enroll.194

An optional bilingual program resembles the voluntary selection plans found unconstitutional in Green $v$. County School Board ${ }^{195}$ and Monroe v. Board of Commissioners. ${ }^{196}$ The Supreme Court held in those cases that school districts with prior de jure segregation were charged with an affirmative duty to take action to

191 Many existing bilingual programs have cultural components. See notes 104-05 supra \& accompanying text.

192 These hypotheses have been supported by studies of the class composition of current bilingual programs. See notes $39-45$ supra \& accompanying text.

193 Bilingual education thus differs from programs like black studies classes that merely teach about minority culture.

194 Under the foreseeability test adopted by the Second, Fifth, and Sixth Circuits, race consciousness and disincentives for Anglo enrollment are clearly unconstitutional. See, e.g., Arthur v. Nyquest, 573 F.2d 134, 141-43 (2d Cir.), cert. denied, 99 S. Ct. 179 (1978); United States v. Texas Educ. Agency, 564 F.2d 162, 168 (5th Cir. 1977), cert. denied, 47 U.S.L.W. 3838 (U.S. July 2, 1979) (No. 78-897); NAACP v. Lansing Bd. of Educ., 559 F.2d 1042, 1046-48 (6th Cir.), cert. denied, 434 U.S. 997 (1977); Morales v. Shannon, 516 F.2d 411 (5th Cir. 1975). See also Armstrong v. O'Connell, 451 F. Supp. 817 (E.D. Wis. 1978). The foreseeability test has been persuasively criticized. E.g., Reading the Mind of the School Board, supra note 181. But see Columbus Bd. of Educ. v. Penick, 47 U.S.L.W. 4924, 4927-28 (U.S. July 2, 1979) (No. 78-610) (foreseeability effects standard may be used as one kind of proof of impermissible purpose). The argument here, however, is that the segregative impact of voluntary bilingual programs is not only foreseeable, but, in fact, planned.

195391 U.S. 430 (1968).

196391 U.S. 450 (1968). 
eliminate racial discrimination "root and branch": simply allowing free transfer among schools was insufficient. ${ }^{197}$

Just as optional integration did not validate the segregation in Green, so it should not validate segregated bilingual programs. In view of the minority-oriented linguistic and cultural techniques of bilingual programs, segregative effects of even voluntary programs should raise suspicions. ${ }^{198}$ The harms of separation-stigma and loss of contact with Anglos ${ }^{109}$-may be as substantial when created by voluntary bilingual education as when by mandatory programs. Whether ethnic animus motivated the institution of the voluntary program likewise may have no impact on the extent of these effects. ${ }^{200}$

On the other hand, an optional bilingual program may in fact be a good faith attempt to provide non-English speaking students meaningful education and may thus have less of a stigmatizing impact. For such programs, the remedial aspect should be considered in determining how important the state interest need be to withstand constitutional challenge.

The state may allege the goal of providing meaningful education to all students in a language they understand, admittedly a compelling state interest. ${ }^{201}$ The least restrictive alternative requirement, however, poses some problems.

The types of alternatives available depend upon the constitutionality of providing non-English speaking students with instruction only in English. If a state's constitutional duty to give all students a meaningful education requires bilingual education, the effects of a segregated bilingual program must be compared with those of an integrated bilingual classroom. The resulting stigma is not offset by educational gain because the comparison group is also a bilingual classroom with identical educational benefits.

Alternatively, if a state may constitutionally eliminate bilingual programs entirely, the appropriate comparison group would not be

197 Green v. County School Bd., 391 U.S. 430, 438, 44I-42 (1968). The Court stated further: "The burden on a school board today is to come forward with a plan that promises realistically to work, and promises realistically to work now." Id. 439 (emphasis in original).

198 The sequence of events in Green, id., was different from that in a voluntary bilingual program. In Green, the voluntary plan was intended to remedy prior de jure segregation. By instituting voluntary bilingual education, a school district is implementing simultaneously both the segregation and the voluntary remedy of Green. This fact difference does not, however, make such bilingual programs any more permissible.

199 See notes 179-83 supra \& accompanying text.

200 See note 181 supra \& accompanying text.

201 See text following note 183 supra. 
an integrated bilingual program, but rather an integrated classroom offering instruction only in English. By choosing to offer instruction not required by the Constitution, the state has created an additional option for the non-English speaking student. The educational advantage of bilingual instruction partly offsets this stigma, at least for non-English speaking students. English speaking minorities, fully capable of learning in a monolingual classroom, may nevertheless feel compelled to participate in bilingual programs. For these persons, who, in fact, typically constitute the plurality group in bilingual education today, ${ }^{202}$ the stigma of segregation is not at all counterbalanced by educational benefits.

The state must therefore demonstrate another state interest when optional bilingual education is challenged by English speaking minorities. The state may allege that, in addition to providing remedial education, two other interests are served by such programs: avoiding the educational harm to Anglos associated with forcing them to enroll in a bilingual program and maximizing individual enrollment choices. The former is admittedly a compelling state interest. In light of the AIR study findings that bilingual techniques can likely educate successfully a group of students of varying linguistic abilities, ${ }^{203}$ the state will have a difficult time proving that the education of Anglos would suffer substantially in a bilingual classroom. The state cannot show, therefore, that a segregated, though voluntary, bilingual program bears a strong relation to its interest in quality education for Anglos.

The state's interest in permitting students or parents to choose for themselves bilingual or monolingual instruction presents a closer question. Parents certainly have a substantial interest in controlling the upbringing of their children, ${ }^{204}$ and children may have additional rights of their own. ${ }^{205}$ The state, however, may

202 See notes $40 \& 43$ supra \& accompanying text.

203 See notes 47-54 supra \& accompanying text. To facilitate integrated bilingual instruction, educators have suggested techniques such as grouping students according to linguistic ability for language instruction, maximizing individual instruction, using a team teaching approach, and employing sufficient bilingual resource teachers and aids for all classrooms. E.g., Cardenas, Bilingual Education, Segregation, and a Third Alternative, 19 InEQuaLITY IN EDUc. 19 (1975); Bunnguar Unit, Colorado State Dep't. of Education (1976). See Fernández \& Guskin, supra note 9, at 14-15.

204 See, e.g., Wisconsin v. Yoder, 406 U.S. 205 (1972); Pierce v. Society of Sisters, 268 U.S. 510 (1925); Meyer v. Nebraska, 262 U.S. 390 (1923).

205 See Wisconsin v. Yoder, 406 U.S. 205, 241 (1972) (Douglas, J., dissenting in part); Goodman, supra note 179, at 384-86. Cf. Tinker v. Des Moines Indep. Comm. School Dist., 393 U.S. 503 (1969) (first amendment rights). 
impose reasonable regulations regarding a child's basic education. ${ }^{208}$ The constitutional rights of parents and children have never extended to dictating the public school's curriculum.

The state's interest in affording maximum choice to students and parents is not sufficiently compelling, for example, to justify separation by race. Even when busing is necessary to achieve racial balance, the combined interests of the state and parents do not outweigh the rights of minority children. ${ }^{207}$ When, therefore, the minority children in a segregated bilingual program are harmed to the same extent as were those in Brown v. Board of Education, ${ }^{208}$ the state's interest in preserving individual choice does not justify isolation of non-English speaking students. Where minimal harm occurs, maximum latitude should be afforded to students' or parents' decisions.

If the state allows enrollment in the program of English speaking minorities, it is, in effect, setting up a program for all minorities, not just those needing special language instruction. Some minority children, pressured from a variety of sources to participate in the bilingual program, ${ }^{209}$ will be involuntarily separated. ${ }^{210}$ The result, stigmatizing these children without any offsetting increment in their educational achievement, requires some greater justification than freedom of choice.

Similarly, freedom of choice cannot justify a program that fosters continued segregation of English speaking minorities after English language proficiency is achieved. One court has thus ruled that a bilingual program discouraging the transfer of English speaking minority children to monolingual classes constituted deliberate segregation:

[The bilingual program director] deliberately conducted [the bilingual program] as a maintenance program and discouraged transfer out of the program. She failed to provide a mechanism for removing students who reached the level of proficiency in the English language which would enable them to understand regular English instruction. Fifty-three students were retained in [the program] after it had served its mandated objective. To that

206 Wisconsin v. Yoder, 406 U.S. 205, 213 (1972).

207 See, e.g., Swann v. Charlotte-Mecklenburg Bd. of Educ., 402 U.S. 1 (1971); Morgan v. Kerrigan, 401 F. Supp. 216 (D. Mass. 1975), aff d, 530 F.2d 401 (1st Cir.), cert. denied, 426 U.S. 935 (1976).

208347 U.S. 483 (1954).

209 See notes 191-94 supra \& accompanying text.

210 See notes 195-98 supra \& accompanying text. 
extent administration of the bilingual program was a perversion of the purpose and a misuse of funds. ${ }^{211}$

An optional bilingual program that is constitutionally impermissible for one of these reasons can be cured. Alternatives other than bilingual education can satisfy statutory obligations ${ }^{212}$ if only a few students require compensatory education. A school board unsuccessful in attracting Anglos to its bilingual program may prohibit participation by English speaking minorities. ${ }^{213}$ Finally, a school board may choose to require some Anglos to enroll in the program.

Forced separation of minorities into bilingual classrooms open only to non-English speaking students is unconstitutional. The same is true of optional programs, open to all, that separate minority students capable of learning in an integrated, monolingual classroom. None of the state interests in such a program-providing meaningful education to linguistic minorities, protecting Anglos from educational disadvantage, and preserving students' and parents' freedom of choice-are sufficient to justify the resulting harm to these minority schoolchildren.

\section{Vi. Bilmngual Programs as Part of Desegregation REMEDIES}

Even if students have no constitutional right to bilingual education, school districts ordered to desegregate have reason to implement bilingual programs. ${ }^{214}$ Bilingual education may be a means of facilitating integration by affording Anglos working knowledge of a second language and appreciation of a different culture. ${ }^{215}$ The combination of desegregation and bilingual education demands have produced three contrary results in the federal courts.

211 Cintron v. Brentwood Union Free School Dist., 455 F. Supp. 57, 63 (E.D.N.Y. 1978) (footnotes omitted). Although the program was thus found to violate the Equal Educational Opportunities Act of $1974, \$ 204,20$ U.S.C. $\$ 1703$ (a) (1978), the decision is relevant to this discussion because the statute's standards of impermissible deliberate segregation are identical to those of the Constitution. See notes 69-71 supra \& accompanying text.

212 See note 102 supra \& accompanying text.

213 This solution, though denying English speaking minorities the benefits of bilingual education, including exposure to their culture and language, may be the least restrictive way of protecting the rights of those who do not wish to enroll. For a discussion of the cultural disadvantages of this solution, see Cultural Pluralism, supra note 9 .

214 For an extensive discussion of this area, see Comment, The Legal Status of Bilingual Education in America's Public Schools: Testing Ground for a Statutory and Constitutional Interpretation of Equal Protection, 17 DuQ. L. REv. 473 (1979).

215 See note 23 supra \& accompanying text. 
In Keyes v. School District No. 1,216 the Tenth Circuit found bilingual education programs inconsistent with a desegregation remedy. The district court had permitted the clustering of students in order to conduct bilingual programs and had therefore decided not to desegregate four elementary schools ${ }^{217}$ with minority enrollments ranging from seventy-seven to eighty-eight percent. ${ }^{218}$ Ruling that bilingual education could not substitute for desegregation ${ }^{219}$ and noting that the fourteenth amendment conveyed no independent right to bilingual education, ${ }^{220}$ the court of appeals reversed without considering the benefits of bilingual education. ${ }^{221}$ The difficulty with the Keyes approach is this implict rejection of the propositions that segregation may produce linguistic difficulties best remedied by bilingual education and that bilingual programs may be an educationally sound method of integrating diverse minority groups.

A district court in Morgan $v$. Kerrigan ${ }^{222}$ ordered a plan similar to the one rejected in Keyes. To accommodate demands for both desegregation and bilingual education, the court first clustered Spanish and Chinese speaking students in the Boston schools in sufficient numbers to insure successful bilingual programs. Blacks and Anglos were then assigned around these clusters with care not to identify any school as a minority school. Despite this distribution policy, the court specifically exempted one school from its thirty percent limitation on "other minority" students. At that school, an Hispanic enrollment of up to sixty-five precent was permitted in order to implement a bilingual program. ${ }^{223}$

The most far-reaching plan was adopted in United States $v$. Texas, ${ }^{224}$ in which a district court found de jure segregation of

216521 F.2d 465 (10th Cir. 1975), cert. denied, 423 U.S. 1066 (1976).

217 Keyes v. School Dist. No. 1, 380 F. Supp. 673, 692 (D. Colo. 1974), affd in part and remanded, 521 F.2d 465 (10th Cir. 1975), cert. denied, 423 U.S. 1066 (1976).

218 Keyes v. School Dist. No. 1, 521 F.2d 465, 479 n.13 (10th Cir. 1975), cert. denied, 423 U.S. 1066 (1976). Minority students constituted approximately $42 \%$ of the district's total student population. Id.

210 Id. 480.

220 Id. 482-83.

221 For a more detailed discussion of the Tenth Circuit's decision, see Cultural Pluralism, supra note 9 , at 156-60.

222401 F. Supp. 216 (D. Mass. 1975), affd, 530 F.2d 401 (1st Cir.), cert. denied, 426 U.S. 935 (1976).

223 Id. 262. The findings of the AIR Study imply that clustering may not increase the achievement of students in a bilingual program. Overview, supra note 30, at 18. Although concentrating non-English speaking students in schools and classrooms may create a financial savings, that alone seems insufficient to justify the resulting segregation.

224342 F. Supp. 24 (E.D. Tex. 1971), affd, 466 F.2d 518 (5th Cir. 1972). 
Mexican-American students. In formulating a remedy the court reasoned:

[S]pecial education consideration ... [shall] be given to the Mexican-American students in assisting them in adjusting to those parts of their new school environment which present a cultural and linguistic shock. Equally clear, however, is the need to avoid the creation of a stigma of inferiority. ... To avoid this result the Anglo-American students too must be called upon to adjust to their Mexican-American classmates, and to learn to understand and appreciate their different linguistic and cultural attributes. The process by which all students participate in a joint learning and adjustment process will not only constitute an educational enrichment but, also, will bring the school system as a whole closer to that goal or state-of-being referred to by the Supreme Court as a "unitary system." 225

The court therefore ordered bilingual-bicultural programs for all students. Other courts, though not going so far as to require bilingual education for all students, have recognized that bilingual programs facilitate integration and have upheld them as an element of a desegration remedy. ${ }^{226}$

In Milliken v. Bradley (Milliken II), ${ }^{227}$ the Supreme Court addressed the problem of student language difficulties: "In short, speech habits acquired in a segregated system do not vanish simply by moving the child to a desegregated school. The root condition shown by this record must be treated directly by special training at the hands of teachers prepared for that task." 228 This acceptance of special programs as part of desegregation remedies is somewhat surprising in light of the Court's insistence that the scope of the remedy be tailored to the scope of the violation. ${ }^{229}$ Showing that, but for the segregation, the same degree of linguistic difficulties

225 Id. 28.

226 Evans v. Buchanan, 447 F. Supp. 982, 1016 (D. Del.), affd, 582 F.2d 750 (3d Cir. 1978) (ordering "curriculum offerings and programs which emphasize and reflect the cultural pluralism of the students"). See United States v. Texas Educ. Agency, 532 F.2d 380, 398 (5th Cir. 1977), cert. denied, 47 U.S.L.W. 3838 (U.S. July 2, 1979) (No. 78-897); Bradley v. Milliken, 402 F. Supp. 1096, 1144 (E.D. Mich. 1975), aff'd, 433 U.S. 267 (1977); Quality Educ. for All Children, Inc. v. School Bd., 385 F. Supp. 803 (N.D. Ill. 1974).

227433 U.S. 267 (1977).

228 Id. 288.

229 See id.; Dayton Bd. of Educ. v. Brinkman, 433 U.S. 406 (1977). 
would not have existed will likely prove difficult. Certainly minorities with a native language other than English experience similar linguistic difficulties in segregated as in desegregated districts. ${ }^{230}$ In any event, Milliken II lends support to the position adopted in Texas and Morgan that a bilingual program may properly be included as part of a desegregation plan.

Although Texas and Morgan both provided for bilingual programs, the former court required integration while the latter countenanced some continued separation. In the context of a desegregation order, the Texas approach has distinct advantages. This plan treats the effects of segregation on all groups by requiring that each gain exposure to the language and culture of the other. It performs a socialization function by combating the mistrust and stereotyping attendant segregation and provides an opportunity for ongoing personal interaction among students of differing national origins. Moreover, integrated classrooms avoid the possibility of any stigma whatsoever attaching to a bilingual program. ${ }^{231}$

The Texas plan does, however, have drawbacks. Some students required to participate might otherwise have chosen a different option. Furthermore, such an approach might be appropriate only in areas with sufficient numbers of minority students. Some clustering may be necessary for optimum educational results in districts with few minority children or with groups speaking a variety of languages. The Texas plan is thus most feasible in districts with close to equal numbers of minority and Anglo students. In other districts, some variation of the Morgan plan may be optimal as long as the maximum possible integration is guaranteed in the "clustered" schools. In all districts, though, bilingual education and integration can work together to provide for all students a quality education consistent with constitutional requirements.

230 The Court did stress that "the need for [the specific educational remedies ordered] flowed directly from constitutional violations" and that these measures were "necessary to restore the victims of discriminatory conduct to the position they would have enjoyed in terms of education." Milliken v. Bradley, 433 U.S. 267, 282 (1977). The Third Circuit has suggested that Milliken authorizes ancillary relief designed to alleviate the pressures of segregation. Evans v. Buchanan, 582 F.2d 750, 768-69 (3d Cir. 1978). See Bradley v. Milliken, 402 F. Supp. 1096, 1144 (E.D. Mich. 1975), aff'd, 433 U.S. 267 (1977) ("Multi-ethnic studies are essential elements of the curriculum of any outstanding school system; desegregation serves only to emphasize the need for inclusion of these studies."). The Supreme Court's opinion in Milliken is not always, however, read so broadly. E.g., Cultural Pluralism, supra note 9, at 159 ("it was not an abuse of discretion for a district court to order a comprehensive reading program as part of a desegregation remedy when that program was narrowly tailored to return the school children to the position they would have been in absent violations").

231 See notes 179-83 supra \& accompanying text. 


\section{ConcLusion}

This Comment has examined the theoretical and legal constraints on the national origin composition of bilingual classrooms. The goals of integration and bilingual education can be seen as compatible or conflicting-given both theoretical and empirical considerations-depending on one's value choices. The position of this Comment is that the two are compatible-that integrated bilingual classrooms can give all students exposure to and appreciation of their own and other cultures and at the same time provide them a sound education.

Although neither the Constitution nor the federal statutes clearly create an obligation to implement bilingual education, such programs have been ordered by HEW and have properly been included as one part of desegregation remedies. The Constitution may not require bilingual education, but any bilingual program implemented, in order to withstand constitutional scrutiny, should be both optional and open to all students. Mandatory, segregated bilingual education is unconstitutional. Any compulsion on the part of a school district forcing the participation of English speaking minority students into segregated programs also renders the program constitutionally impermissible. 